\title{
The role of horizontal model resolution in assessing the transport of CO in a middle latitude cyclone using WRF-Chem
}

\author{
C. A. Klich and H. E. Fuelberg \\ Department of Earth, Ocean and Atmospheric Science, Florida State University, Tallahassee, 32306-4520, Florida, USA \\ Correspondence to: H. E. Fuelberg (hfuelberg@ fsu.edu)
}

Received: 21 April 2013 - Published in Atmos. Chem. Phys. Discuss.: 5 June 2013

Revised: 8 December 2013 - Accepted: 10 December 2013 - Published: 21 January 2014

\begin{abstract}
We use the Weather Research and Forecasting with Chemistry (WRF-Chem) online chemical transport model to simulate a middle latitude cyclone in East Asia at three different horizontal resolutions $(45,15$, and $5 \mathrm{~km}$ grid spacing). The cyclone contains a typical warm conveyor belt (WCB) with an embedded squall line that passes through an area having large surface concentrations (> $400 \mathrm{ppbv}$ ) of carbon monoxide (CO). Model output from WRF-Chem is used to compare differences between the large-scale $\mathrm{CO}$ vertical transport by the WCB (the $45 \mathrm{~km}$ simulation) with the smaller-scale transport due to its convection (the $5 \mathrm{~km}$ simulation). Forward trajectories are calculated from WRF-Chem output using the Hybrid Single Particle Lagrangian Integrated Trajectory (HYSPLIT) model. At $45 \mathrm{~km}$ grid spacing, the WCB exhibits gradual ascent, lofting surface $\mathrm{CO}$ to $6-$ $7 \mathrm{~km}$. Upon reaching the warm front, the WCB and associated $\mathrm{CO}$ ascend more rapidly and later turn eastward over the Pacific Ocean. Convective transport at $5 \mathrm{~km}$ resolution with explicitly resolved convection occurs much more rapidly, with surface $\mathrm{CO}$ lofted to altitudes greater than $10 \mathrm{~km}$ in $1 \mathrm{~h}$ or less. We also compute CO vertical mass fluxes over specified areas and times to compare differences in transport due to the different grid spacings. Upward CO flux exceeds $110000 t \mathrm{~h}^{-1}$ in the domain with explicit convection when the squall line is at peak intensity, while fluxes from the two coarser resolutions are an order of magnitude smaller. Specific areas of interest within the $5 \mathrm{~km}$ domain are defined to compare the magnitude of convective transport to that within the entire $5 \mathrm{~km}$ region. Although convection encompasses only a small portion of the $5 \mathrm{~km}$ domain, it is responsible for $\sim 40 \%$ of the upward CO transport. We also examine the vertical transport due to a short wave trough and its associated area of convection, not related to the cyclone, that lofts
\end{abstract}

CO to the upper troposphere. Results indicate that fine-scale resolution with explicitly resolved convection is important when assessing the vertical transport of surface emissions in areas of deep convection.

\section{Introduction}

Anthropogenic emissions are transported at atmospheric scales ranging from turbulence to global phenomena. Where and how these emissions are transported can have major impacts on air quality (e.g., Ellingsen et al., 2008) and can affect radiative forcing and other physical and dynamical processes that impact Earth's climate (e.g., Park et al., 2001). Accurately modeling pollution transport is crucial to understanding atmospheric chemistry and its effects on the environment.

Surface-based pollutants are transported most efficiently when they are lofted to the middle or upper troposphere where wind speeds generally are stronger than near the surface. Three primary mechanisms can loft pollutants from the boundary layer to the free troposphere: (1) airstreams such as the warm conveyor belt (WCB) that are associated with middle latitude cyclones (Bey et al., 2001; Cooper et al., 2002; Hannan et al., 2003; Kiley and Fuelberg, 2006), (2) orographic lifting (Henne et al., 2004; Chen et al., 2009; Ding et al., 2009), and (3) deep convection (Lawrence et al., 2003; Liu et al., 2003; Hess, 2005; Halland et al., 2009; Zhao et al., 2009). Although all three transport mechanisms are important, middle latitude cyclones and deep convection are the most variable and difficult to simulate accurately using meteorological or chemical transport models (CTMs).

Although middle latitude cyclones and their associated WCBs can occur virtually anywhere in the middle and polar 
latitudes (Stohl et al., 2002), distinct maxima are located off the east coasts of North America and Asia (Stohl, 2001; Eckhardt et al., 2004). The long-range synoptic-scale WCBrelated transport of atmospheric pollutants has been studied across both the Pacific Ocean (e.g., Jaffe et al., 1999; Yienger et al., 2000; Bey et al., 2001; Carmichael et al., 2003; Heald et al., 2003; Jacob et al., 2003; Liu et al., 2003; Cooper et al., 2004) and Atlantic Ocean (Stohl and Trickl, 1999; Cooper et al., 2001, 2002; Naja et al., 2003; Li et al., 2005; Fehsenfeld et al., 2006; Singh et al., 2009). Anthropogenic emissions across eastern Asia have been increasing rapidly (Richter et al., 2005; Ohara et al., 2007; Zhang et al., 2007, 2009), and their transport to the western United States (US) has been shown to increase local surface ozone concentrations (Jacob et al., 1999; Fiore et al., 2002; Jaffe et al., 2004; Oltmans et al., 2008; Zhang et al., 2008; Reidmiller et al., 2009; Lin et al., 2012). Asian emissions sometimes extend as far as Europe (Stohl et al., 2007; Fiedler et al., 2009).

A great deal of transport modeling has been done using global CTMs whose typical grid spacing is approximately $2^{\circ}$ latitude $\times 2.5^{\circ}$ longitude (Park et al., 2001; Liu et al., 2003; Liang et al., 2004; Li et al., 2005). However, such coarse grid resolution can produce deficiencies in the results. Large spatial gradients of tracer concentrations result from complex interactions between emissions, meteorological conditions, and nonlinear atmospheric chemistry (Constantinescu et al., 2008; Srivastava et al., 2001a, b). Coarse grids artificially diffuse these large gradients, and coupled with highly nonlinear chemistry, may adversely affect the predicted pollutant concentrations. Furthermore, coarse resolution models excessively diffuse the concentrations of atmospheric pollutants, thereby underestimating their amounts in the upper troposphere (Heald et al., 2003; Lin et al., 2010).

In terms of resolving specific meteorological phenomena, coarse resolution models capture large-scale transport processes such as the WCBs (Harrold, 1973) that originate in the warm sector of a cyclone and ascend ahead of the surface cold front (Carlson, 1980). These cyclones and their WCBs are thought to be the dominant form of synoptic-scale transport in the middle latitudes (Harrold, 1973), and the primary mechanism for rapidly exporting air pollution from Asia to North America (Cooper et al., 2002, 2004; Stohl et al., 2002).

Conversely, the meteorological conditions that influence the development of deep convection, such as mixing depth, local thermodynamic variability, and wind velocity, are best resolved by models having much higher resolution than current global CTMs (Lin et al., 2009). Furthermore, once deep convection forms it cannot be adequately resolved at coarse grid spacings. Since the scale of the convection ranges from a few kilometers for small isolated cells to tens or hundreds of kilometers for organized systems such as squall lines or other mesoscale convective systems (Markowski and Richardson, 2010), the explicit resolution of convection requires a horizontal grid spacing less than $\sim 5 \mathrm{~km}$. Lackmann (2011) recently recommended a grid spacing less than $4 \mathrm{~km}$ to achieve explicit convective resolution. This recommendation is supported by recent studies such as Baldauf et al. (2011) and Weisman et al. (2007). We will use the term "explicit resolution" with the understanding that even a $4-5 \mathrm{~km}$ grid spacing is insufficient to resolve all details of convection; cloud resolving models with grid spacings of a few meters are needed for that purpose.

Since convection is not explicitly simulated in coarse resolution models, it must be parameterized using various cumulus parameterization schemes. There is uncertainty and subjectivity in selecting the best cumulus parameterization for a specific study. However, the important point is that no parameterization scheme will provide the detailed representation provided by higher resolution models in which parameterization is not employed. Each scheme varies in its assumptions and methodology and may produce considerably different results (Doherty et al., 2005; Taylor, 2011). Furthermore, it is not advisable to disable convective parameterization and attempt to simulate convection explicitly at coarse resolution because results have revealed slow forming, large convective storms that are not observed in nature (Weisman et al., 1997; Sato et al., 2008).

Many middle latitude cyclones have deep convection embedded in their WCBs. This embedded convection enhances the overall WCB transport, and may even exceed the synoptic-scale component in weaker cyclones (Purvis et al., 2003; Kiley and Fuelberg, 2006). During periods of summertime deep convection, as much as $50 \%$ of pollutants in the boundary layer is transported to the free troposphere by thunderstorms (Thompson et al., 1994). Convection with strong updrafts can loft surface emissions to the tropopause $(\sim 9-$ $15 \mathrm{~km}$ altitude) as quickly as $30 \mathrm{~min}$ (Thompson et al., 1997). Values of carbon monoxide (CO) downwind of deep convection near tropopause altitude have been observed to be three times greater than background values (Pickering et al., 1996).

Few studies have quantified the differences in atmospheric chemical simulations that result from using relatively highversus lower-resolution models. Lin et al. (2010) compared results from a global model with two high-resolution regional atmospheric chemistry models: the global Model for Ozone and Related Tracers (MOZART v2) (Horowitz et al., 2003) run at $1.9^{\circ} \times 1.9^{\circ}$ grid spacing, with the Weather Research and Forecasting with Chemistry (WRF-Chem) model (Grell et al., 2005) and the Community Multiscale Air Quality model (CMAQ) (Byun and Schere, 2006) run at $36 \times 36 \mathrm{~km}$ grid spacing. Deep convection was parameterized in both models. Results showed that both the vertical lifting and outflow of Asian pollution were enhanced in the regional models throughout their study period. Nonetheless, $36 \mathrm{~km}$ grid spacing still is too coarse to resolve most aspects of deep convection. Therefore, it is important to investigate vertical transport using even higher resolution models. A model grid spacing of $12 \mathrm{~km}$ produced the best agreement between simulated and measured concentrations of $\mathrm{O}_{3}$ and $\mathrm{O}_{3}$ precursors in Mexico City (Tie et al., 2010), with poorer 
performance at both larger and smaller spacing. Chock et al. (2002) concluded that coarse resolution leads to faulty representations of ozone and nitrogen oxide chemistry. Similarly, simulated concentrations of particulates over central Europe agreed best with observations when the model grid spacing was $7 \mathrm{~km}$ instead of $28 \mathrm{~km}$ (Wolke et al., 2012). Using a high-resolution (hundreds of meters) regional scale two-dimensional (2-D) model, Halland et al. (2009) found that a single squall line during its $8 \mathrm{~h}$ lifetime could transport as much as 96 metric tonnes $(t)$ of $\mathrm{CO}$ upward and $67 t$ downward at $300 \mathrm{hPa}$.

This study focuses on the transport of $\mathrm{CO}$ within a middle latitude cyclone containing deep convection. Although WRF-Chem simulates the chemical production and loss of CO, because CO's lifetime is several months (Jacob, 1999), it generally can be considered an inert tracer. We employ the WRF-Chem model run at horizontal grid spacings of 45, 15, and $5 \mathrm{~km}$. Unlike Halland et al. (2009), we employ threedimensional (3-D) simulations to capture the full scope of convective transport. We compare transport based on convective parameterization (45 and $15 \mathrm{~km}$ ) with that using explicitly resolved convection $(5 \mathrm{~km})$, i.e., no convective parameterization. Results will show the importance of highresolution modeling when examining convective transport. Section 2 provides information on the data used, WRF-Chem configurations, and calculation methods. Section 3 presents a synoptic overview, Sect. 4 the results, and Sect. 5 the summary and conclusions.

\section{Data and methodology}

\subsection{Study domain}

Our study domain encompassed a typical middle latitude cyclone in East Asia (Figs. 1-2). A detailed synoptic overview is provided in Sect. 3. The simulations began at 00:00 UTC, 22 May 2008, and ended five days later at 00:00 UTC, 27 May, spanning the entire life cycle of the cyclone. Output from the first $12 \mathrm{~h}$ of the runs is not used in the discussions that follow to allow sufficient time for model spin-up.

Model simulations were made using three nested domains (Fig. 1). The outer domain (D1) covered most of eastern Asia with a horizontal grid spacing of $45 \mathrm{~km}$. This relatively coarse spacing simulated large-scale features of the cyclone such as its WCB. An embedded nested domain (D2) had a grid spacing of $15 \mathrm{~km}$, and the innermost nested domain (D3) had a $5 \mathrm{~km}$ spacing that provided explicit resolution of deep convection embedded within the WCB. The wave cyclone was completely contained within D2 during its life cycle (Fig. 2), and all important meteorological features were located far from the boundaries of D1 to reduce undesirable boundary effects (Warner et al., 1997). All three domains contained 50 sigma levels, most tightly packed in the boundary layer and near the tropopause.

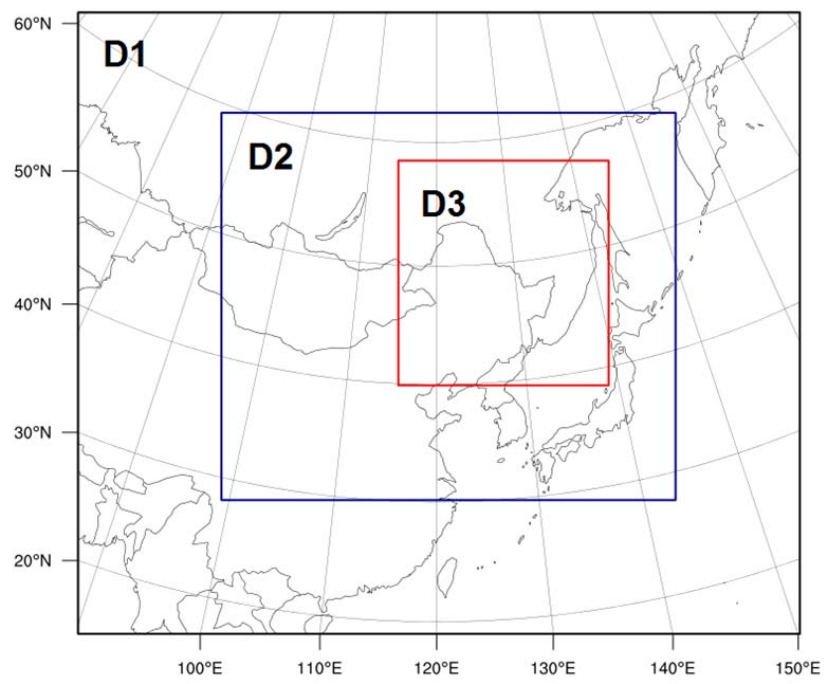

Fig. 1. The three domains used in the WRF-Chem simulations. Domain one (D1) has a horizontal grid spacing of $45 \mathrm{~km}$, domain 2 (D2) $15 \mathrm{~km}$, and domain 3 (D3) $5 \mathrm{~km}$.

\subsection{Model specifics}

We used WRF-Chem Version 3.4, an online chemical transport model coupled with the Advanced Research WRF (ARW) dynamical core (Grell et al., 2005). In an attempt to produce the best simulations possible, full chemistry runs were made instead of using the passive tracer option since air quality involves the interaction of meteorological factors and chemical processes (Grell et al., 2005). WRF-Chem is a fully compressible, non-hydrostatic, terrain-following model that is integrated on the Arakawa C-grid (Skamarock et al., 2008). It includes Runge-Kutta 2nd and 3rd order time integration schemes and advection schemes up to the 6th order. Damping is included near the model top of $50 \mathrm{hPa}$ to prevent gravity waves from reflecting off the upper boundary.

Meteorological initial and boundary conditions were obtained from the National Centers for Environmental Protection (NCEP) final analysis on a $1^{\circ} \times 1^{\circ}$ grid at 26 pressure levels (http://dss.ucar.edu/datasets/ds083.2/). The boundary conditions were updated every $6 \mathrm{~h}$. Four-dimensional data assimilation (nudging) was used at $6 \mathrm{~h}$ intervals on the outer two domains. The recommended nudging coefficient $\left(0.0003 \mathrm{~s}^{-1}\right.$, Gilliam and Pleim, 2010) helped the simulations represent real-world conditions without being overly constrained. Other model settings and parameterizations are given in Table 1. An especially important choice was the Grell-3-D cumulus parameterization (ARW WRF User's Guide, 2012) that is an updated version of the earlier GrellDevenyi scheme (Grell and Devenyi, 2002). This parameterization, used only in D1 and D2, allows coarsely resolved subsidence to be spread to neighboring columns. Without this scheme, the downward motion between convective clouds is not well represented (Tzella and Legras, 2011). No cumulus 

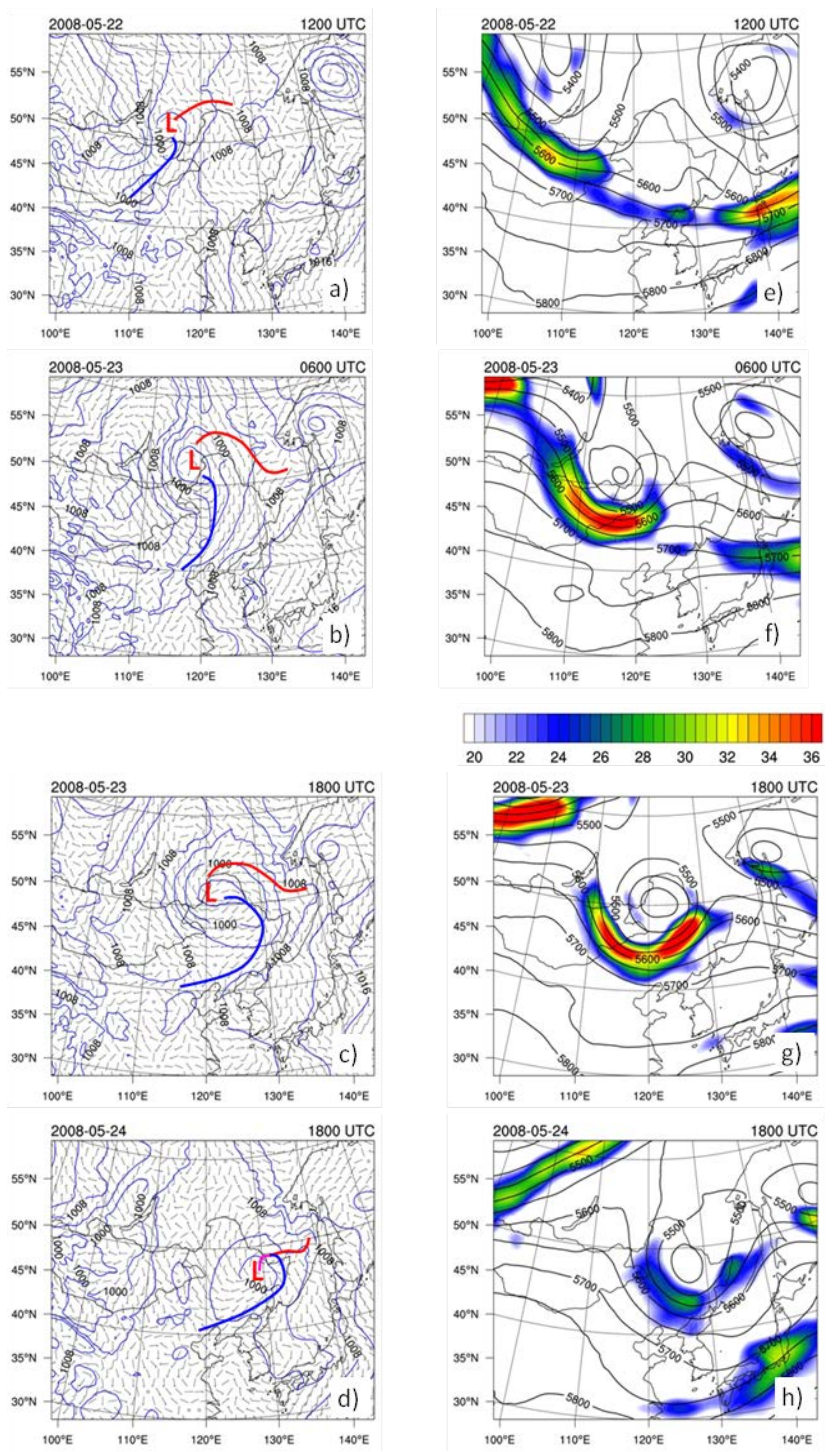

Fig. 2. Domain 2 of the WRF-Chem simulation. (a-d) Sea level pressure $\left(\mathrm{hPa}\right.$, blue contours) and $10 \mathrm{~m}$ winds $\left(\mathrm{m} \mathrm{s}^{-1}\right)$ during the life cycle of the middle latitude cyclone. The surface location of the cyclone is shown (red "L"), as are its cold front (thick blue line), warm front (thick red line), and occluded front (thick purple line). (e-h) $500 \mathrm{hPa}$ heights ( $\mathrm{m}$, black contours) and wind speed $\left(\mathrm{m} \mathrm{s}^{-1}\right.$, color filled contours) at the same times as (a-d).

parameterization was used in the $5 \mathrm{~km}$ domain, i.e., the convection was explicitly resolved to the extent possible at $5 \mathrm{~km}$ grid spacing.

WRF-Chem contains several options for simulating chemical interactions. We used the regional Atmospheric Chemistry Mechanism (RACM) for gas phase chemistry, which is based on the older Regional Acid Deposition Model, version 2 (RADM2, Stockwell et al., 1997). Although RACM simulates over 100 chemical species and their reactions, we focus on $\mathrm{CO}$ due to its long residence time of approxi-
Table 1. WRF-Chem configurations used in the model simulations.

\begin{tabular}{ll}
\hline Option & Configuration \\
\hline $\begin{array}{l}\text { Cumulus Parameterization } \\
\text { Shortwave Radiation } \\
\text { Longwave Radiation }\end{array}$ & $\begin{array}{l}\text { Grell-3-D (Grell and Devenyi, 2002) } \\
\text { Goddard (Chou et al., 2001) } \\
\text { Rapid Radiative Transfer Model } \\
\text { (Mlawer et al., 1997) }\end{array}$ \\
Microphysics & Lin Microphysics (Lin et al., 1983) \\
Planetary Boundary Layer & Yonsei University (Hong et al., 2006) \\
Land Surface & Noah Land Surface Model (Ek et al., 2003) \\
Chemical Scheme & RACM (Stockwell et al., 1997) \\
Aerosol Scheme & GOCART (Chin et al., 2000) \\
Photolysis & Madronich (Madronich, 1987) \\
\hline
\end{tabular}

mately 1-2 months (e.g., Novelli et al., 1998). The Georgia Tech/Goddard Global Ozone Chemistry Aerosol Radiation and Transport (GOCART) aerosol parameterization (Chin et al., 2000) was used. GOCART is a bulk aerosol scheme that does not contain specific information about particle size or concentration, but instead calculates changes in total aerosol mass.

We performed three WRF-Chem simulations. The first utilized all three domains in Fig. 1 and included two-way nesting. Since we also wanted to examine larger-scale meteorological features without the influence of the fine-scale resolution provided by $\mathrm{D} 3$, we performed two other simulations, one using only D1 and D2 with two-way nesting, and the other only D1. These three simulations permitted an examination of the WCB, its convection, and the relationship between the two at both coarse and fine resolutions.

The Hybrid Single Particle Lagrangian Integrated Trajectory Model (HYSPLIT; Draxler and Hess, 1998; and http: //ready.arl.noaa.gov/HYSPLIT.php) was used as a complement to WRF-Chem to describe the different modes of transport over time. Using the WRF-Chem simulations as input, HYSPLIT allowed us to create forward and backward trajectories at any starting location from any of the three simulations.

\subsection{Emissions data}

Several sets of emissions data were used to model the transport of CO. WRF-Chem was initialized with chemical data from MOZART-4 (Emmons et al., 2010). MOZART-4 also was used to update WRF-Chem's lateral boundary conditions at $6 \mathrm{~h}$ intervals. The archived data have a horizontal resolution of $1.9^{\circ} \times 2.5^{\circ}$ with 56 vertical levels. Initial conditions also included biomass burning emissions from the Fire INventory from NCAR (FINN, Wiedinmyer et al., 2011). Anthropogenic source emissions were from the REanalysis of the TROpospheric data set (RETRO, http://retro.enes.org). RETRO is a data set of chemical composition at a resolution of $0.5^{\circ} \times 0.5^{\circ}$ that is mapped onto the WRF-Chem grid using a program created by the Brazilian Centro de Previsão de Tempo e Estudos Climáticos (CPTEC). Biogenic emissions were calculated online within WRF-Chem 
based on atmospheric conditions and land use data from the Model of Emissions of Gases and Aerosols from Nature (MEGAN, Guenther et al., 2006). MEGAN is a highresolution $\left(\sim 1 \mathrm{~km}^{2}\right)$ data set that includes leaf area index, vegetation type, and specific emission factors.

\section{Case study}

\subsection{Synoptic overview}

Our case study period (00:00 UTC, 22 May-00:00 UTC, 27 May 2008) focused on a typical middle latitude cyclone over eastern Asia with a well-defined WCB and associated deep convection (Fig. 2). The northeast part of D2 also included a separate dissipating low pressure system over the Sea of Okhotsk. The southwest parts of D1 and D2 encompassed the high terrain of the Himalayas. This section presents an overview of the synoptic, mesoscale, and surface CO characteristics during the life cycle of the major cyclone based on the WRF-Chem simulations. Later paragraphs will show that the simulations agree closely with observed conditions.

The surface low formed in eastern Mongolia near 12:00 UTC 22 May (Fig. 2a). It then moved slowly eastward into northeast China by 06:00 UTC, 23 May (Fig. 2b), reaching its lowest central pressure of $992 \mathrm{hPa}$. After 12:00 UTC, 23 May, the cyclone slowly weakened (Fig. 2c), and during the next 24 to $36 \mathrm{~h}$ (Fig. 2d) it gradually moved southeastward along the border of northeast China and Russia while continuing to dissipate.

The frontal structure of the cyclone was typical. We manually located the warm, cold, and occluded fronts (Fig. 2a-d) using standard meteorological parameters from WRF-Chem. The surface cold front was characterized by a well-defined wind shift from southwesterly ahead of the front to northwesterly behind, a strong gradient of dew point and temperature, and a low pressure trough. The cold front slowly moved eastward with its parent low, eventually reaching the coast of northeast China (Fig. 2c). The warm front was less defined than the cold front. It moved little as the low slowly drifted eastward, and the system became occluded by 00:00 UTC, 24 May (Fig. 2d).

Conditions at $500 \mathrm{hPa}$ also were typical of middle latitude cyclones. A short wave trough deepened to form a closed low by 06:00 UTC, 23 May (Fig. 2e-f), as wind speeds increased to $40 \mathrm{~m} \mathrm{~s}^{-1}$ (Fig. 2f). Enhanced synoptic-scale ascent southeast of the low (not shown) coincided with the formation of a squall line ahead of the cold front. The low continued to deepen, and the area of strongest winds on its eastern side (Fig. 2g) intensified to create a well-defined westerly jet stream. The low and associated jet weakened by 18:00 UTC, 24 May (Fig. 2h).

The $500 \mathrm{hPa}$ pressure level exhibited a second feature of interest (Fig. 2e-h). A short wave trough separate from the middle latitude cyclone began to develop over northeast
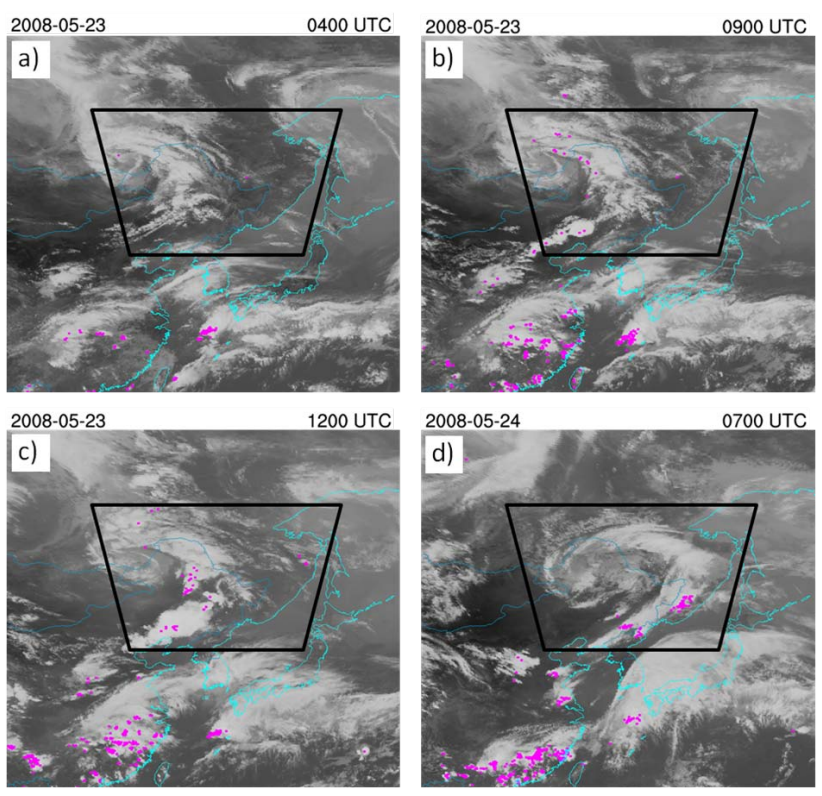

Fig. 3. Infrared imagery from MTSAT-1R and lightning data from WWLLN (pink) at four times of deep convection during the WRFChem simulation. The black box outlines the area of domain D3 at $5 \mathrm{~km}$ resolution.

China at 00:00 UTC, 23 May, with a wind maximum between $30-35^{\circ} \mathrm{N}$ and $115-120^{\circ} \mathrm{E}$. The trough slowly moved eastward, gradually increasing in strength. It approached the Pacific coast by 18:00 UTC, 23 May (Fig. 2g), and by 07:00 UTC, 24 May, winds east of the trough exceeded $25 \mathrm{~m} \mathrm{~s}^{-1}$ near southern Japan (Fig. 2h). The deep convection associated with the trough, as well as its flow patterns that produced CO transport, are discussed in Sect. 4.

Our simulations closely represent the natural atmosphere. Observed infrared imagery (Fig. 3) from the Multifunctional Transport Satellite (MTSAT-1R) is consistent with the simulations in Fig. 2. The cyclone exhibited a classic commashaped cloud pattern. As the system intensified and eventually became occluded (Fig. 3b-d), the band of clouds ahead of the cold front became better defined, signifying the location of the WCB described in Sect. 4. Similarly, close agreements were found between other observed and simulated parameters, e.g., locations of the cyclone, its central pressure, and associated fronts (not shown).

\subsection{Mesoscale features}

Two major areas of deep convection occurred during the study period: a squall line ahead of the surface cold front, and a multi-cellular complex over southeast China near the southern boundary of D1 (Fig. 3). The squall line ahead of the cold front formed near 02:00 UTC, 23 May, and dissipated just after 12:00 UTC, 23 May. Although much of this modeled convection dissipated overnight (local time $=\mathrm{UTC}+8 \mathrm{~h}$ ), some remnants of the squall line continued. Thunderstorm clusters 

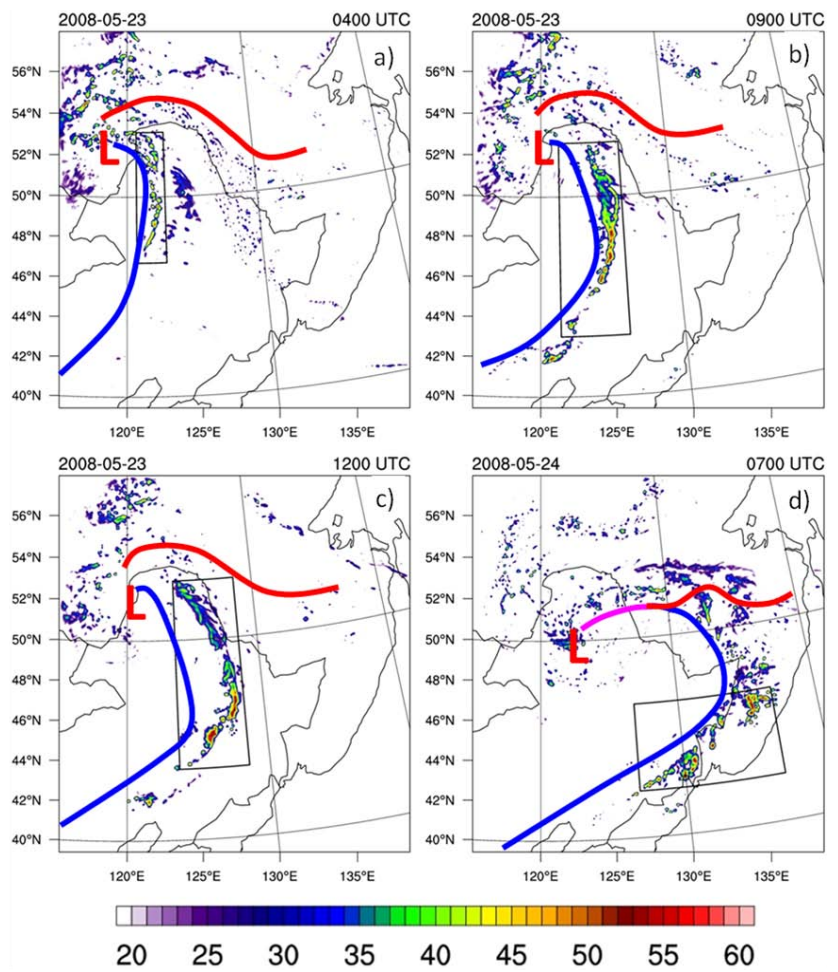

Fig. 4. WRF-Chem simulated composite reflectivity (dBZ) within D3 from formation to dissipation of the squall line (a-c) and coastal convection (d). The times shown are the same as those in Fig. 3. Locations of the surface low, cold front (blue), warm front (red) and occluded front (pink) also are shown. Black boxes around the convection are areas of interest (AOIs) used for flux calculations in Sect. 4.

regenerated ahead of the cold front along the coast late in the morning of 24 May (Fig. 3d, 4d). Although this convection did not constitute a squall line, the individual cells continually re-formed over the same areas for several hours (Fig. 3d).

Lightning occurs when there is a deep layer of mixed phase hydrometeors, generally signifying tall clouds with vigorous updrafts. We used data from the World Wide Lightning Location Network (WWLLN) to locate lightning flashes during the time of most intense convection. WWLLN has a detection efficiency of approximately $20 \%$ in our study region (Rodger et al., 2009) and a location accuracy of 5-10 km (Rodger et al., 2004). Despite this limited detection, previous studies have successfully used the data to locate deep convection (e.g., Abarca et al., 2010). WWLLN-derived lightning flashes were summed over $1 \mathrm{~h}$ periods between a half hour before and half hour after each satellite image and superimposed on the images (pink dots in Fig. 3). There was no lightning early in the morning of 23 May (Fig. 3a); however, high cloud tops and lightning developed within a few hours (Fig. 3b). The convection and its associated lightning continued for several hours (Fig. 3c) and dissipated late on 23 May. Less intense, disorganized convection was simulated
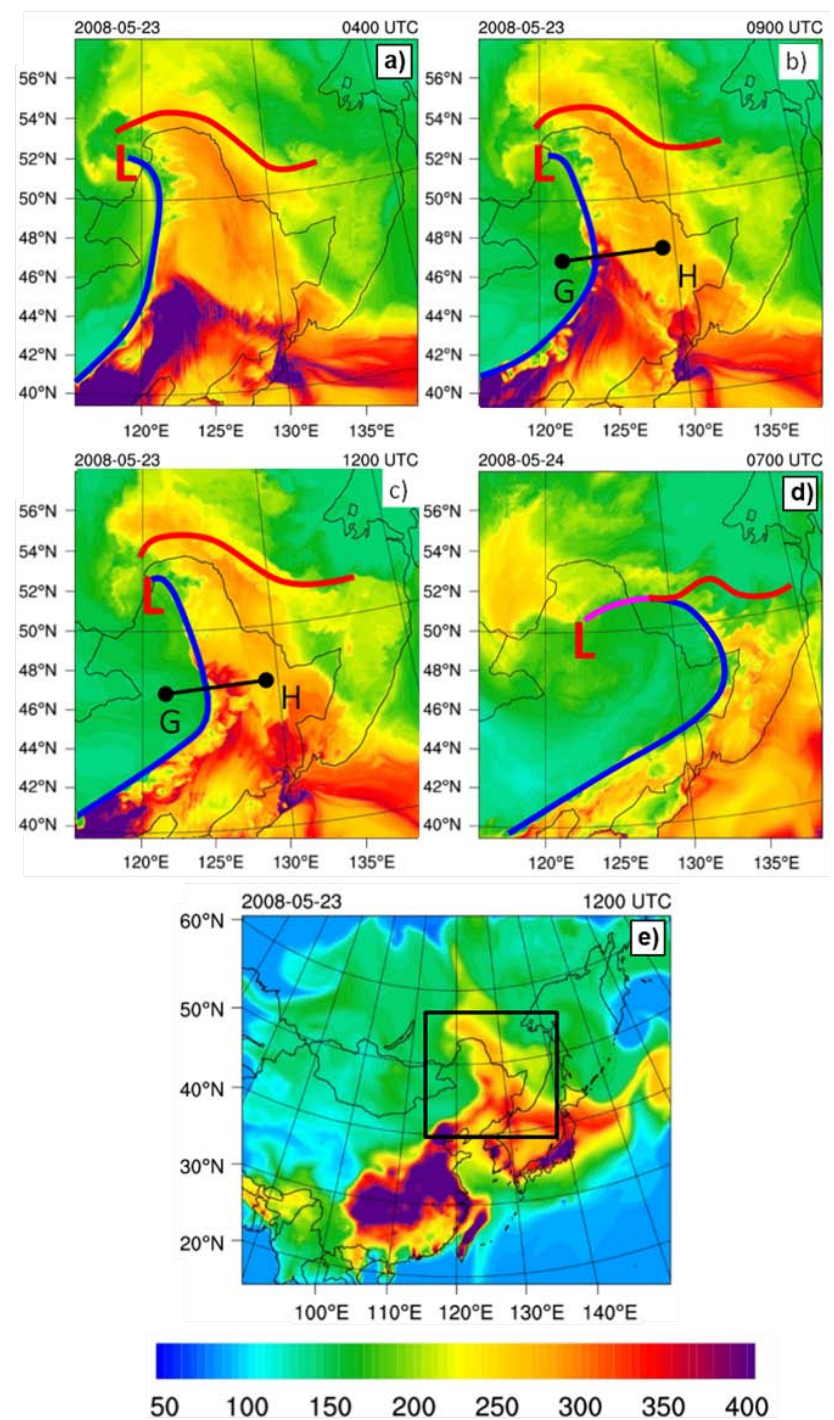

Fig. 5. Surface CO concentrations (ppbv) in D3 (a-d) and D1 (e) of our WRF-Chem simulation. The surface low, cold front (blue), warm front (red), and occluded front (purple) are shown for D3. The black box in (e) is the area of D3. Axes of cross section G-H used in Fig. 11 are shown in (b-c).

northwest of the surface low in the far northwest part of D3, consistent with the satellite imagery (Fig. 3b-c).

Comparisons of Figs. 3-4 reveal that locations of the WRF-Chem simulated deep convection agree closely with those observed by satellite, again confirming the quality of the simulations. The squall line within D3 (Fig. 4) was located ahead of the surface cold front and exhibited simulated reflectivities exceeding $55 \mathrm{dBZ}$ (Fig. $4 \mathrm{~b}-\mathrm{c}$ ) when the maximum number of lightning flashes was observed (Fig. 3bc). The line propagated from near the border of China and Mongolia to the border of China and Russia, a distance of approximately $700 \mathrm{~km}$. Strong updrafts and downdrafts 

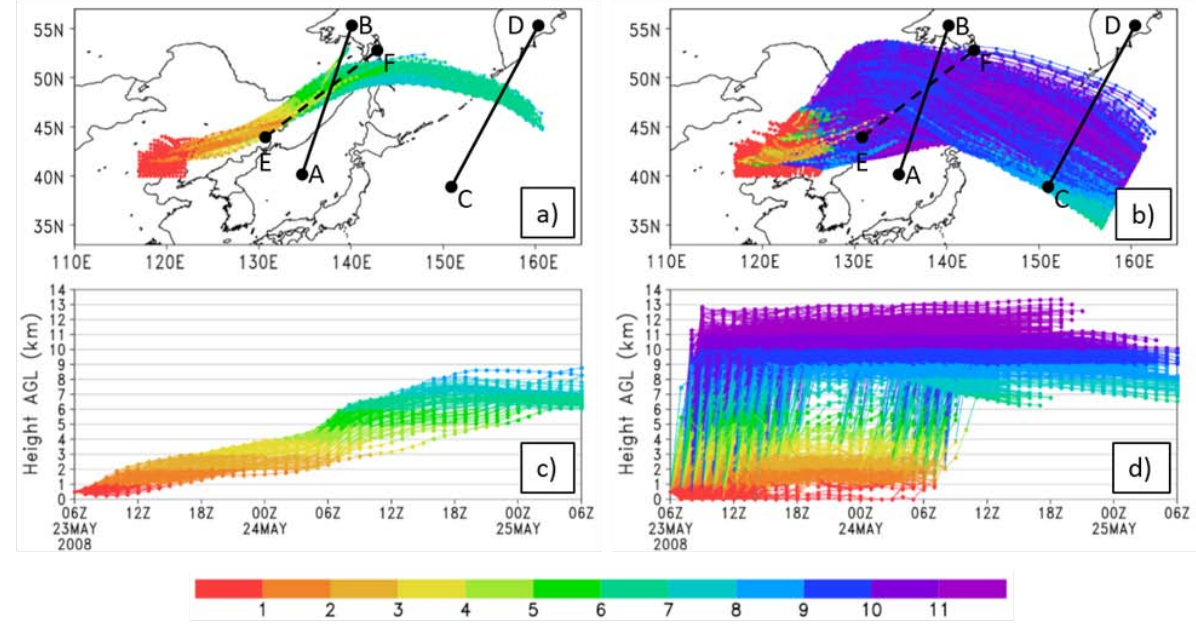

Fig. 6. HYSPLIT trajectories from D1 (a, c) and D3 (b, d) using WRF-Chem output. Axes for cross sections used in Figs. 7 and 10 also are shown (black lines). Colors indicate the heights of trajectories $(\mathrm{km})$.

accompanying the squall line produced vertical transport of boundary layer pollution that is described in Sect. 4.

The second major area of deep convection, multi-cell storms in southeast China just south of $30^{\circ} \mathrm{N}$, began near 04:00 UTC, 23 May (Fig. 3a), and persisted through 14:00 UTC, 24 May (not shown), producing nearly $36 \mathrm{~h}$ of continuous convection. These storms were associated with large-scale ascent east of the upper level short wave trough (Fig. 2f-h).

\subsection{Surface CO}

Eastern Asia contains some of the world's most substantial anthropogenic surface emissions (Richter et al., 2005; Ohara et al., 2007; Zhang et al., 2007, 2009). The greatest level of $\mathrm{CO}$ during our period (> $400 \mathrm{ppbv}$ ) was located in domain D1, just south of D3 in eastern China (Fig. 5e). Some of the concentration-enhanced $\mathrm{CO}$ was advected into $\mathrm{D} 3$ by southerly winds (Fig. 2), producing concentrations that exceed $400 \mathrm{ppbv}$ over the extreme southern part of that smaller domain (Fig. 5a). The cyclonic flow transported CO northward, wrapping around the center of the low (Fig. 5a-c) after occlusion (Fig. 5d). The cold front was marked by a strong horizontal CO gradient (Fig. 5b-c), with air behind the front containing as much as $250 \mathrm{ppbv}$ less $\mathrm{CO}$ than ahead. The horizontal gradient of surface $\mathrm{CO}$ concentration across the warm front was not as great as with the cold front.

The convection in southeast China within D1 (Fig. 3) occurred where $\mathrm{CO}$ concentrations exceeded $400 \mathrm{ppbv}$ over a wide area (Fig. 5e). Since this area was located in the domain having $45 \mathrm{~km}$ grid spacing, the convection was parameterized, and Sect. 4 will show that its vertical transport of surface $\mathrm{CO}$ is relatively weak compared to that of the explicitly resolved convection in D3.
The squall line in D3 influenced surface concentrations of $\mathrm{CO}$ (Fig. 5). Since convection rapidly lofts polluted boundary layer air to the free troposphere, the surface CO concentration value beneath strong updrafts often is smaller than in surrounding areas. Additionally, downdrafts typically transport relatively small values of $\mathrm{CO}$ from the middle troposphere to the surface. The effects of these convective scale vertical motions are apparent in Fig. $5 \mathrm{~b}\left(40^{\circ} \mathrm{N}, 120^{\circ} \mathrm{E}\right)$ and Fig. $5 \mathrm{c}\left(44^{\circ} \mathrm{N}, 125^{\circ} \mathrm{E}\right)$ as isolated areas of surface $\mathrm{CO}$ values as small as $150 \mathrm{ppbv}$, compared to surrounding environmental values exceeding $300 \mathrm{ppbv}$. When WRF-Chem was run at grid spacings greater than the $5 \mathrm{~km}$ in D3 (not shown), the fine-scale variations in $\mathrm{CO}$ concentration are not evident. Thus, high-resolution models can reveal at least some localized surface variations in $\mathrm{CO}$ that are due to a storm's updrafts and downdrafts. As noted previously, even finer scale details of the $\mathrm{CO}$ field would require even smaller grid spacing.

\section{Results}

\subsection{Parameterized convection at $45 \mathrm{~km}$ resolution}

Simulations performed using only outer domain D1 (45 km resolution, Fig. 1) reveal synoptic-scale aspects of the WCB and its transport of CO. We used WRF-Chem output from this single-domain simulation to calculate forward trajectories using HYSPLIT. Areas of southwesterly surface winds far south of the parent low and just in advance of the cold front were considered the initiation area of the WCB, i.e., between $40-46^{\circ} \mathrm{N}$ and $117-126^{\circ} \mathrm{E}$ (Fig. 6a). Trajectories were launched at each model grid point ( $45 \mathrm{~km}$ spacing) at $500 \mathrm{~m}$ above ground level. The trajectories were initialized at 06:00 UTC, 23 May, and continued for $48 \mathrm{~h}$ or until they left 

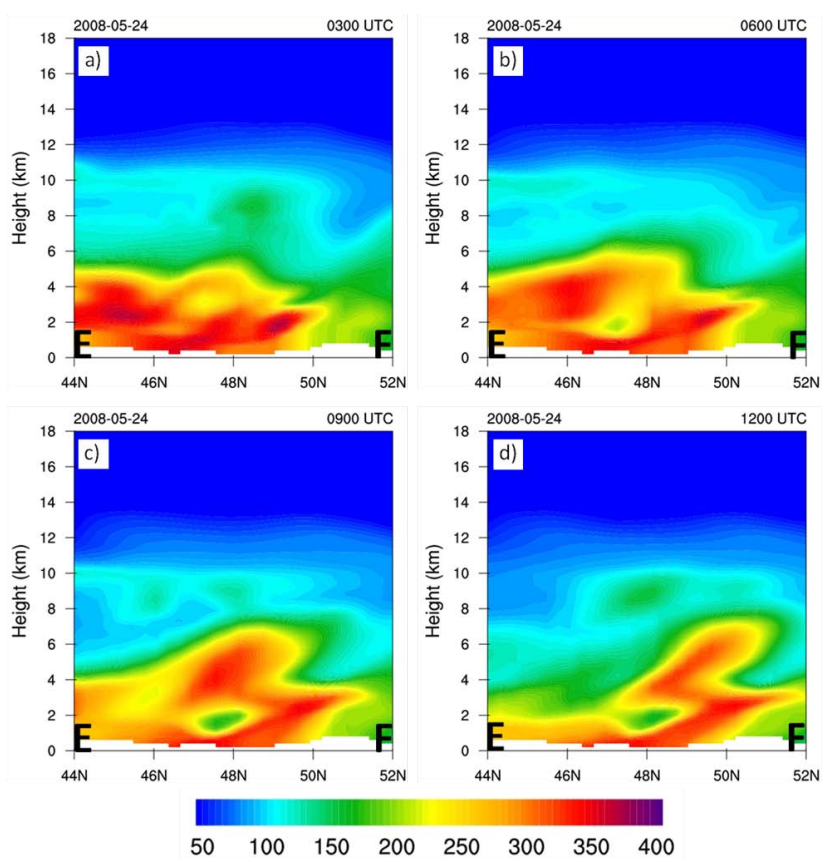

Fig. 7. Vertical cross sections of CO (ppbv) along axis E-F in Figs. 6a, b and 8a, c. Values were obtained from WRF-Chem using output from D1 only.

the model domain (Fig. 6a, c), the period when the middle latitude cyclone and associated WCB were best developed (Fig. 5b).

From this large number of trajectories, we isolated those representing the WCB by using criteria from Eckhardt et al. (2004). They required $48 \mathrm{~h}$ trajectories to travel eastward a distance exceeding $10^{\circ}$ longitude, northward at least $5^{\circ}$ latitude, and vertically at least $60 \%$ of the average tropopause height at the ending latitude. The typical tropopause height in our simulation region was $11-12 \mathrm{~km}$, yielding a $48 \mathrm{~h}$ ascent criterion of at least $6.5 \mathrm{~km}$. Applying these criteria isolated approximately 100 trajectories that represented the WCB (Fig. 6a, c).

The WCB derived from the $45 \mathrm{~km}$ grid spacing exhibits gradual ascent from the boundary layer to the free troposphere (Fig. 6c). It remains in the boundary layer ahead of the cold front for the first $6 \mathrm{~h}$ (Fig. 6c) and then begins to ascend through the troposphere, rising $\sim 3 \mathrm{~km}$. When it reaches the warm front near the border of eastern China and southeast Russia (Fig. 6a), the ascent becomes more rapid, approximately $3 \mathrm{~km}$ during the next $6 \mathrm{~h}$ period. Once reaching the middle troposphere, the WCB turns more easterly (Fig. 6a). Maximum altitudes never exceed $\sim 8 \mathrm{~km}$ (Fig. $6 \mathrm{c}$ ).

The starting trajectory locations are in an area of enhanced $\mathrm{CO}$ concentrations (> $400 \mathrm{ppbv}$, Fig. 5). A cross section of $\mathrm{CO}$ (Fig. 7) along the axis of the WCB (line E-F in Fig. 6a) during the period of maximum ascent (03:00 UTC, 24 May to 12:00 UTC, 24 May) reveals values of $\sim 300$ ppbv gradually being lofted to $6-8 \mathrm{~km}$.
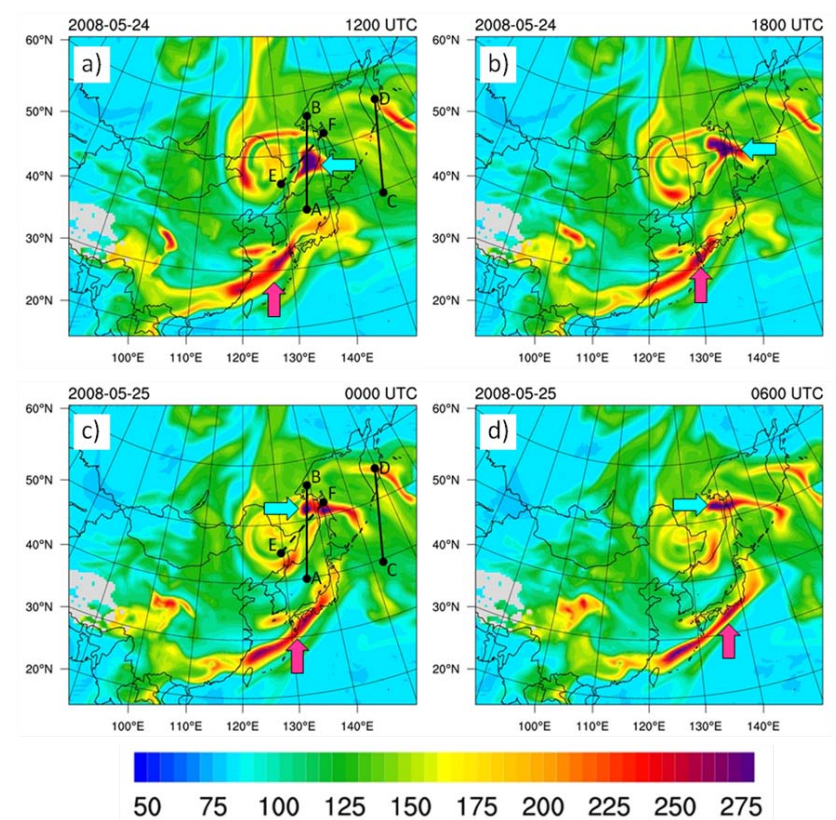

Fig. 8. CO concentration (ppbv) at $5 \mathrm{~km}$ altitude for the singledomain run. Axes of cross sections are shown in (a) and (c). The pink and red arrows refer to specific $\mathrm{CO}$ features described in the text.

Plan views of $\mathrm{CO}$ at an altitude of $5 \mathrm{~km}$ (Fig. 8) also reveal the evolution of the WCB related plume. As the WCB reaches the warm front between 12:00 UTC and 18:00 UTC, 24 May (Fig. 2d), it begins to transport CO eastward (tealcolored arrows in Fig. 8b-d). This transport is evident by an area of concentration-enhanced CO exceeding $275 \mathrm{ppbv}$ in southeast Russia. Enhanced CO also wraps around the center of the low in northeast China, probably due to splitting of the WCB into clockwise and counterclockwise components. A portion of the $\mathrm{CO}$ plume then begins to advect eastward over the Sea of Okhotsk and eventually over the Pacific Ocean (Fig. 8c-d).

Cross sections perpendicular to the trajectories in Fig. 6 were prepared at selected times. Before 24 May (Fig. 9a), most of the $\mathrm{CO}$ along axis A-B in Fig. 6a is confined to the boundary layer. However, as the middle latitude cyclone and accompanying cold front move eastward, the WCB becomes much more efficient at transporting $\mathrm{CO}$ aloft. Just $16 \mathrm{~h}$ later (Fig. 9b), a large amount of $\mathrm{CO}$ has been transported from the boundary layer to $7-8 \mathrm{~km}$. The concentration-enhanced $\mathrm{CO}$ remains near this altitude while transported eastward (Fig. 8). As the WCB-related CO plume moves farther east over the Pacific Ocean, it becomes diffused both vertically (cross section C-D in Fig. 9c) and horizontally (Fig. 8c).

The CO pattern at $5 \mathrm{~km}$ (Fig. 8) exhibits another notable feature that is unrelated to the WCB. Synoptic-scale ascent in the middle troposphere over southeast China due to the short wave trough (Fig. 2e-f) produces widespread, persistent deep convection east of the trough line beginning near 04:00 UTC, 

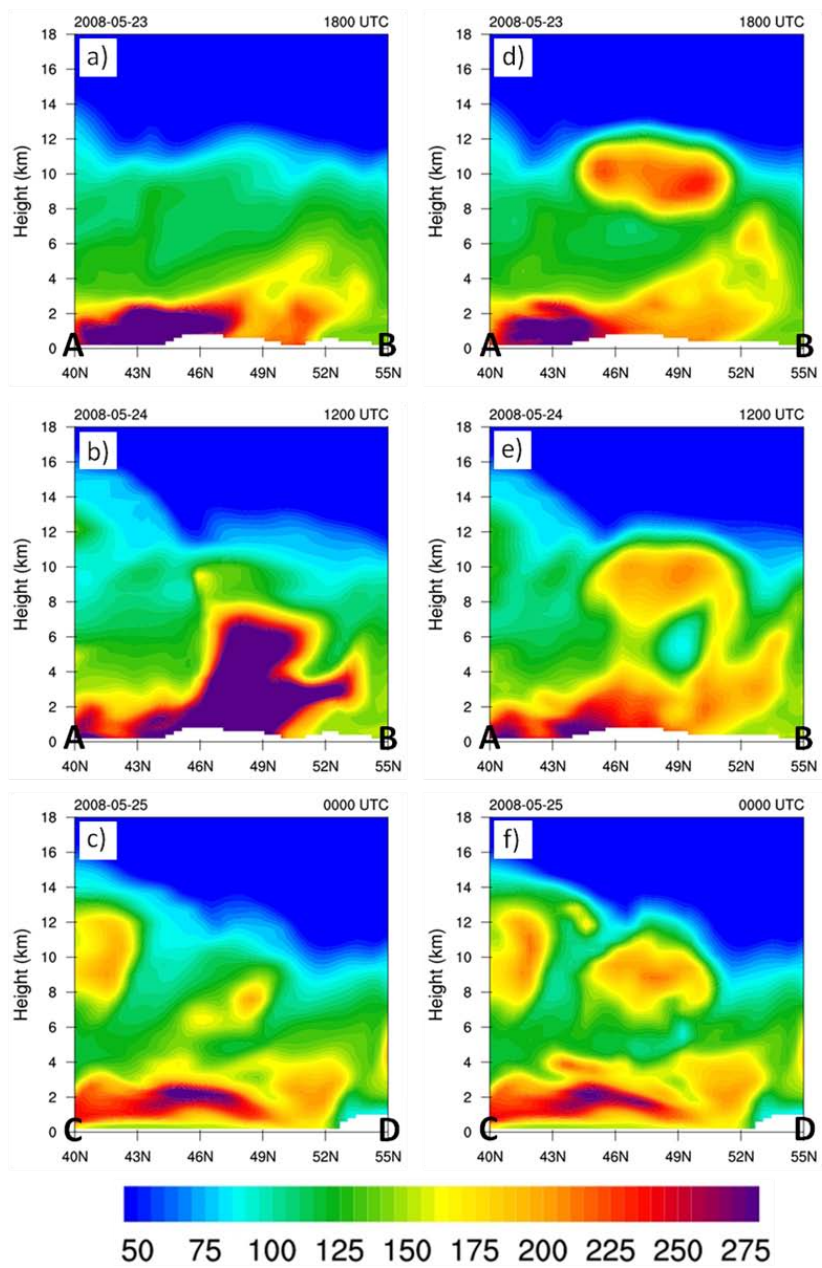

$\begin{array}{llllllllll}50 & 75 & 100 & 125 & 150 & 175 & 200 & 225 & 250 & 275\end{array}$

Fig. 9. Vertical cross sections of CO (ppbv) perpendicular to different locations along the trajectories in Fig. 6 for both the singledomain run (a-c) and three-domain run $(\mathbf{d}-\mathbf{f})$. Locations of cross sections A-B and C-D are shown in Figs. 6 and 8.

23 May. This ascent causes surface-based CO to be transported into the middle troposphere south of $35^{\circ} \mathrm{N}$, producing a northeast-to-southwest band of concentration-enhanced $\mathrm{CO}$ (red arrows in Fig. 8). Trajectories were launched at $500 \mathrm{~m}$ between $23-30^{\circ} \mathrm{N}$ and $105-120^{\circ} \mathrm{E}$ at 00:00 UTC, 23 May, before the first lightning flashes in the area (Fig. 10), allowing parcels to encounter the convection as it forms. The criteria used to define a WCB (Eckhardt et al., 2004) also were used here, although this feature is not part of the WCB or middle latitude cyclone. Approximately 50 trajectories matched the criteria.

Since the grid spacing of D1 only allows convection to be parameterized, the associated vertical motions develop slowly and remain relatively weak (Weisman et al., 1997; Sato et al., 2008). Thus, the trajectories exhibit little ascent at 04:00 UTC, 23 May, when the storms first begin (Figs. 3a, $10 \mathrm{~b})$. Although the trajectories are in the area of developing convection for $\sim 3 \mathrm{~h}$, they remain near the surface until
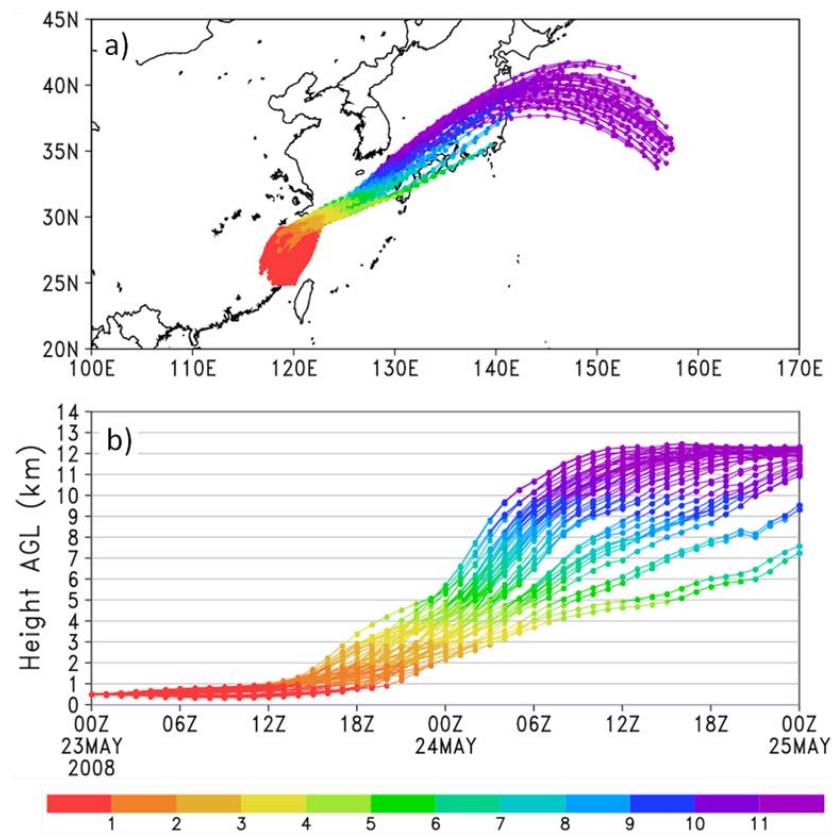

Fig. 10. HYSPLIT trajectories from D1 using WRF-Chem output, as in Fig. 6a-b. Deep convection begins to form over southwest China near 04:00 UTC, 23 May, due to a short wave trough in the middle troposphere (Fig. 2e-h). This convection is unrelated to the middle latitude cyclone or its WCB.

$\sim$ 12:00 UTC before starting to ascend into the free troposphere. This delay is due to the very weak vertical motion near the surface $\left(\sim 0.5 \mathrm{~cm} \mathrm{~s}^{-1}\right.$ at 06:00 UTC, 23 May). At 18:00 UTC (Fig. 10b) vertical motion at $2 \mathrm{~km}$ increases to $\sim 15 \mathrm{~cm} \mathrm{~s}^{-1}$, and by 00:00 UTC, 24 May, when the parcels are just offshore, vertical motion is near $30 \mathrm{~cm} \mathrm{~s}^{-1}$. The trajectories continue to ascend offshore (Fig. 10) by 03:00 UTC. At 06:00 UTC (Fig. 10b), the ascent weakens, and the parcels begin a more horizontal motion toward the southeast. Their altitudes range from 4 to $11 \mathrm{~km}$. The increasing vertical motion gradually lofts $\mathrm{CO}$ to $5 \mathrm{~km}$ along a line stretching from north of Taiwan to Japan (see red arrows in Fig. 8). Similar evolution of $\mathrm{CO}$ is evident in the upper troposphere (not shown).

Our second set of simulations employed a horizontal grid spacing of $15 \mathrm{~km}$ (D2 in Fig. 1). Convection is still parameterized at this resolution, and although the grid spacing is one-third that of D1, mesoscale circulations in the real atmosphere still are poorly resolved. Abbreviated results from D2 will be given at the end of the following section. We next focus on results from D3.

\subsection{Explicit convection at $5 \mathrm{~km}$ resolution}

The explicitly resolved squall line within D3 at $5 \mathrm{~km}$ grid spacing (Fig. 1) is associated with much stronger vertical motions than in D1, allowing parcels to quickly reach high altitudes. Forward trajectories were launched at $5 \mathrm{~km}$ grid 
spacing within D3. Their area of release was the same as for D1 (40-46 ${ }^{\circ} \mathrm{N}, 117-126^{\circ} \mathrm{E}$; Fig. 6). The trajectories began at $500 \mathrm{~m}$ above ground level on 06:00 UTC, 23 May 2008, and ran for $48 \mathrm{~h}$. Because the area of D3 is small compared to D2 and D1 (Fig. 1), most trajectories exit the D3 domain well before $48 \mathrm{~h}$. When a trajectory left D3, it was continued into D2 using the WRF-Chem wind data at $15 \mathrm{~km}$ spacing. A similar procedure was followed for trajectories leaving D2 and entering D1.

The vertical criterion used to isolate WCB-related trajectories in D1 is not appropriate here because Eckhardt et al. (2004) did not use the small grid spacing that enables explicit convective resolution. Therefore, although we used the same horizontal criteria as in D1, we chose a height criterion of $10 \mathrm{~km}$ instead of the previously used $6.5 \mathrm{~km}$. Over 2000 trajectories met both the horizontal displacement and $10 \mathrm{~km}$ height criteria (Fig. 6b-d).

There are major differences between trajectories launched from D1 and D3. Trajectories from D3 ascend rapidly as the squall line strengthens near 06:00 UTC, 23 May (Fig. 6d). Some reach an altitude of $10-13 \mathrm{~km}$ in only $1 \mathrm{~h}$ due to the strong vertical motions simulated by the explicitly resolved convection. The $13 \mathrm{~km}$ ascent over $1 \mathrm{~h}$ corresponds to an average vertical velocity of $\sim 3.6 \mathrm{~m} \mathrm{~s}^{-1}$. Although $1-2$ orders of magnitude greater than observed for the $45 \mathrm{~km}$-based trajectories (Fig. 6c), the simulated vertical motions nonetheless are small compared to those occurring in mature thunderstorms in nature (e.g., Markowski and Richardson, 2010). Even finer scale horizontal resolution would be needed to better simulate observed updraft speeds. The higher altitudes and broader range of the $5 \mathrm{~km}$ trajectory altitudes $(\sim 6-$ $13 \mathrm{~km}$ ) compared to the $45 \mathrm{~km}$ trajectories is consistent with the results of Lin et al. (2010) who examined model results at $36 \mathrm{~km}$ and $1.9^{\circ}$ lat/long grid spacing. The rapid ascent continues for $6-10 \mathrm{~h}$ as individual trajectories encounter the simulated convective regions. The vertical transport weakens between 18:00 UTC, 23 May, and 03:00 UTC, 24 May (Fig. 6d), as the squall line dissipates but the coastal convection has not yet begun. The coastal convection begins near 03:00 UTC, 24 May, as does renewed rapid ascent. Once the coastal convection dissipates after 08:00 UTC, the rapid vertical transport ends. The higher resolution trajectories are spread over a noticeably wider area and deeper layer (Fig. 6b) than those derived from the coarser resolution data (Fig. 6a). This spread occurs because the simulated convection at $5 \mathrm{~km}$ resolution produces a broader range of storm tops, and therefore a broader range of horizontal wind directions and speeds (not shown). Since wind speeds in the upper troposphere are much faster than at lower altitudes, the pollutants are quickly advected eastward. Few trajectories from D1 reach the edge of the domain within $48 \mathrm{~h}$; however, a majority of D3 trajectories do so.

Most of the D3 trajectories begin near an area of CO exceeding $400 \mathrm{ppbv}$ (Fig. 5). The combination of strong vertical motion and large $\mathrm{CO}$ concentrations leads to strong ver- tical transport of CO. The simulated squall line exhibits a long, linear structure and passes between $120^{\circ} \mathrm{E}$ and $130^{\circ} \mathrm{E}$ (Fig. 4a-c) between 07:00 UTC and 12:00 UTC. A time sequence of east-to-west cross sections of $\mathrm{CO}$ through this region along $47^{\circ} \mathrm{N}$ (Fig. 11) shows the evolution of the convective transport. Before the squall line develops (Fig. 11a), there is little vertical transport, with most of the CO confined to the boundary layer. An hour later as the convection forms (Fig. 11b), CO already has been lofted to $\sim 11 \mathrm{~km}$ in a narrow region that corresponds to a convective "cell" as simulated at $5 \mathrm{~km}$ resolution. By 09:00 UTC (Fig. 11c), when the squall line is longest and near peak intensity, a large amount of $\mathrm{CO}$ is being transported from the boundary layer to $12 \mathrm{~km}$. As the air reaches the tropopause near $11 \mathrm{~km}$ altitude, the CO spreads horizontally, both eastward and westward. This spreading is consistent with the structure of squall lines observed in nature (e.g., Markowski and Richardson, 2010). The squall line continues to propagate eastward between 10:00 UTC and 11:00 UTC 23 May (Fig. 11d-e), lofting additional CO into the upper troposphere. By 12:00 UTC (Fig. 11f), the squall line begins to exit the region of the cross section but continues to develop further south (not shown).

Cross sections of $\mathrm{CO}$ along the axis of the squall line at 09:00 UTC, 23 May, reveal the cellular nature of the simulated convection (Fig. 12). Since the squall line is bowshaped at this time, two cross sections were prepared, along $\mathrm{I}-\mathrm{J}$ and $\mathrm{J}-\mathrm{L}$ (axes shown in Fig. 13b). The southern portion of the squall line (axis I-J) consists of relatively young, developing "cells" (as depicted at $5 \mathrm{~km}$ resolution) that are typical of many squall lines occurring in nature (e.g., Markowski and Richardson, 2012). Conversely, the more mature cells are located farther north (axis J-K). The southern, younger, portion of the squall line exhibits regions of strong upward CO transport (Fig. 12a) that are surrounded by regions of diminished transport where the convection either is weaker or completely absent. The greatest vertical transport is located on the right side of cross section I-J, in the central portion of the squall line, where $\mathrm{CO}$ values reaching $350 \mathrm{ppbv}$ have been lofted above $10 \mathrm{~km}$. The northern, older section of the squall line (axis J-K in Fig. 12b) also has transported large amounts of $\mathrm{CO}$ upward, but the upper tropospheric $\mathrm{CO}$ concentrations are somewhat weaker, and the vertical plumes less defined, especially in the right half of the cross section. This is evidence of the weakening convection, and the transport of $\mathrm{CO}$ downwind of the squall line and away from the axis of the cross section.

The upward CO transport continues as the squall line passes through its life cycle. This quasi-continuous transport produces a large area of concentration-enhanced $\mathrm{CO}$ in the upper troposphere $(10 \mathrm{~km}$, Fig. 13) that originated near the surface. When the squall line first was forming (04:00 UTC, 23 May, Fig. 13a), relatively weak values of $\mathrm{CO}$ are evident at $10 \mathrm{~km}$. However, at 09:00 UTC, 23 May (Fig. 13b), CO at $10 \mathrm{~km}$ has increased greatly in the areas of convection. By 12:00 UTC (Fig. 13c), even more CO has been lofted to 

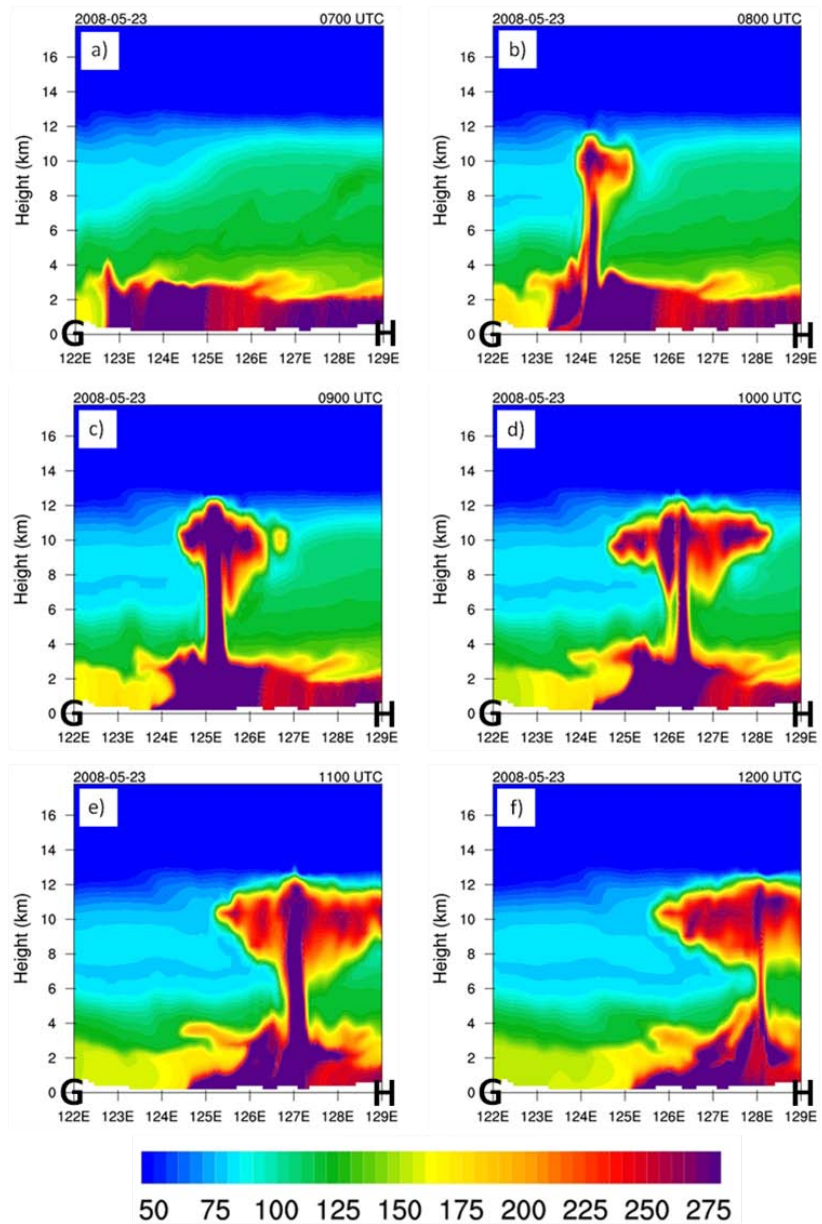

Fig. 11. Vertical cross sections of $\mathrm{CO}$ (ppbv) through the squall line in D3 (5 km grid spacing) at hourly intervals between 07:00 and 12:00 UTC, 23 May. The axis of cross section G-H is shown in Fig. 5b, c.

$10 \mathrm{~km}$, and the area of enhanced $\mathrm{CO}$ has grown quite large, with embedded values exceeding $275 \mathrm{ppbv}$. The shape of the concentration-enhanced $\mathrm{CO}$ feature is similar to that of the squall line that produced it during the previous several hours (Fig. 4a-c). The two-way nesting of the three-domain WRFChem simulation (Fig. 1) allows the convectively transported $\mathrm{CO}$ at $10 \mathrm{~km}$ to be advected downwind, out of D3 and into D1 (not shown), passing over the Sea of Okhotsk and Pacific Ocean.

The day after the squall line saw the development of multicell storms along the frontal boundary (Figs. 3d, 4d). Although the multi-cells produce distinct areas of convective lofting to $12 \mathrm{~km}$ (Fig. 12c), the CO pattern at that altitude is not as continuous or as intense as produced by the squall line the previous day (Fig. 12a, b). This occurs because the coastal multi-cells exhibit weaker updrafts and because surface $\mathrm{CO}$ concentrations in the multi-cell storm area are less, e.g., over North Korea, China, and Russia (Fig. 5d).
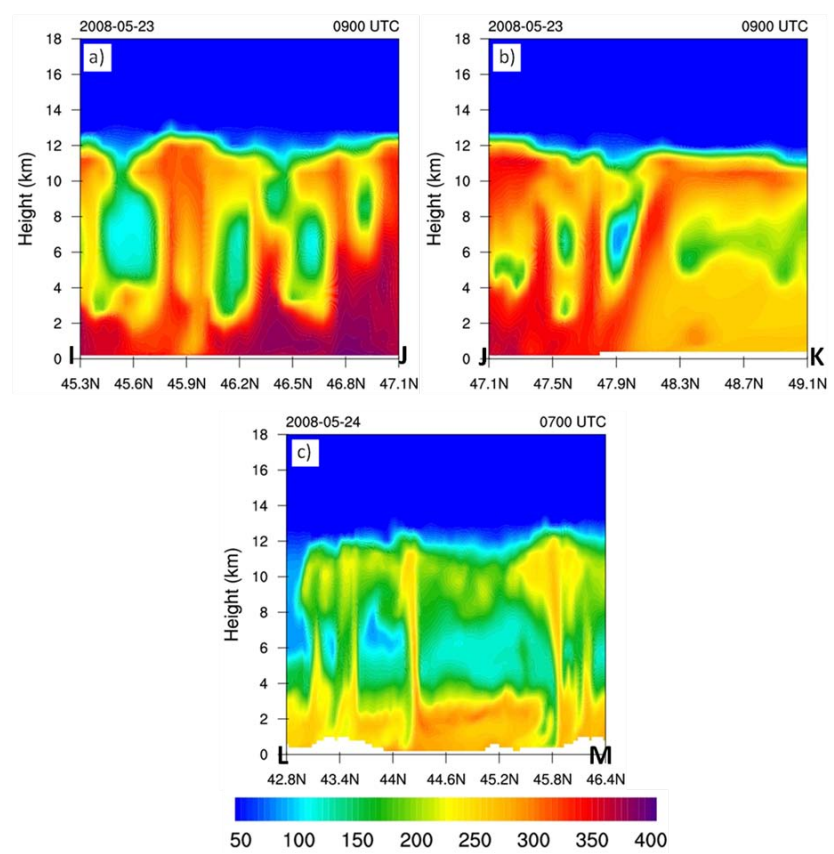

Fig. 12. Vertical cross sections of CO (ppbv) parallel to the squall line (a, b) at 09:00 UTC, 23 May, and through the multi-cell convective region (c) at 07:00 UTC, 24 May, using WRF-Chem output from D3. Axes of the two cross sections are shown in Fig. 13b, d.

\subsection{Vertical fluxes of $\mathrm{CO}$}

To quantify the vertical transport of $\mathrm{CO}$ due to our differing model resolutions, we computed vertical CO mass fluxes for several altitudes and areas. The flux was computed following the technique of Halland et al. (2009) that is given by

$M=\frac{\mathrm{MC} \times w \times A \times t}{1000}$

where $\mathrm{MC}$ is the mass concentration of $\mathrm{CO}\left(\mathrm{kg} \mathrm{m}^{-3}\right), w$ is vertical velocity $\left(\mathrm{m} \mathrm{s}^{-1}\right), A$ is the area of the model grid box being used $\left(\mathrm{km}^{2}\right)$, and $t$ is the time increment (hourly in our simulations). Thus, $M$ represents the vertical mass flux integrated over area and time with the units in metric tonnes $(t)$. For the sake of brevity, we frequently will refer to $M$ as simply "mass flux" in the discussions that follow. Using output from WRF-Chem, MC can be calculated using the ideal gas law:

$\mathrm{MC}=\frac{P_{\mathrm{L}} \times M \times C}{R \times T}$

where $P_{\mathrm{L}}$ is the pressure level of the flux computation, $M$ is the molecular weight of $\mathrm{CO}, \mathrm{C}$ is the model-derived $\mathrm{CO}$ concentration, $R$ is the universal gas constant, and $T$ is the model-derived temperature.

To compare fluxes from the three different WRF-Chem simulations $(45,15,5 \mathrm{~km})$, we computed values within D3. That is, grid point values within the area of D3 were added, 

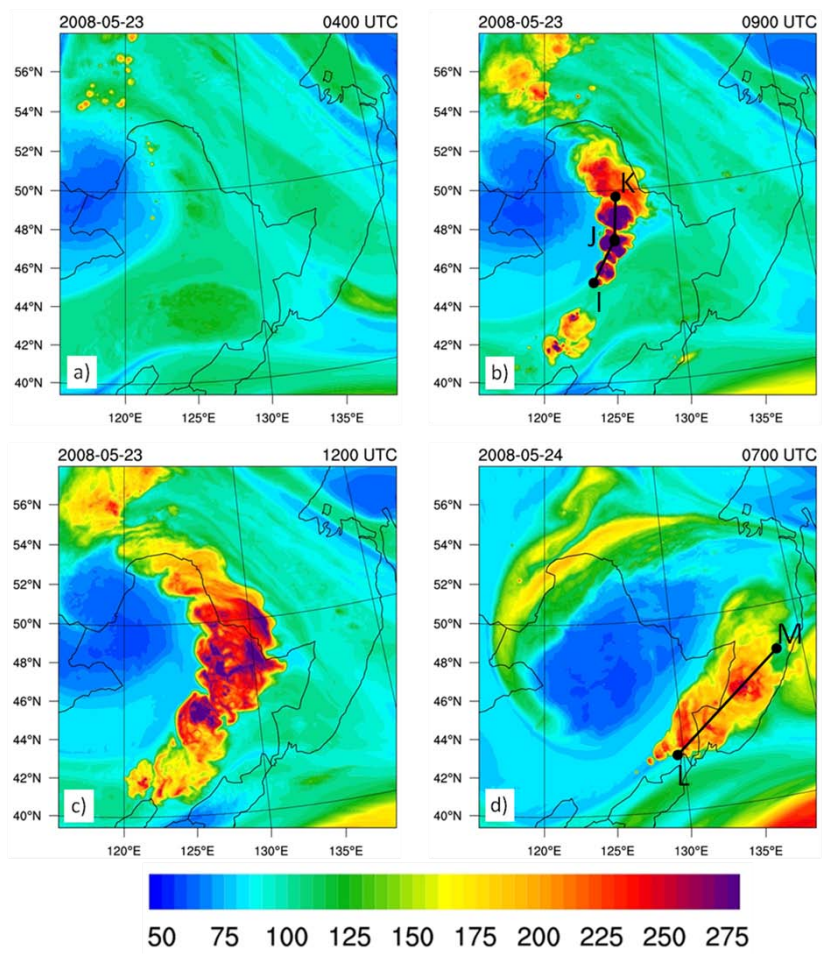

Fig. 13. CO concentration (ppbv) at $10 \mathrm{~km}$ at four different times using WRF-Chem output from D3. Axes of cross sections I-J at 09:00 UTC, 23 May (b) and L-M at 07:00 UTC, 24 May (d) that are used in Fig. 12 also are shown.

and we "zoomed in" on D1 and D2 to encompass only the D3 model domain. Although D1 and D2 contained fewer grid points than D3 itself, all three areas were the same $\left(\sim 4106200 \mathrm{~km}^{2}\right)$. We computed CO mass flux at $500 \mathrm{hPa}$ at hourly intervals over a $36 \mathrm{~h}$ period, starting at 00:00 UTC, 23 May. The $500 \mathrm{hPa}$ pressure level often is near the altitude of maximum atmospheric vertical motions.

D3 produces substantially greater upward and downward CO flux than D1 or D2 even before the convection begins. At 00:00 UTC, 23 May (Fig. 14) upward values for the $1 \mathrm{~h}$ period are $\sim 50000 t \mathrm{~h}^{-1}$. Downward flux is $-40000 t \mathrm{~h}^{-1}$, creating a net flux of $\sim 10000 t \mathrm{~h}^{-1}$. The enhanced mesoscale forcing that ultimately leads to squall line development begins near 03:00 UTC (Fig. 14), causing a rapid increase in both upward and downward $\mathrm{CO}$ flux. The squall line itself begins to form shortly after 07:00 UTC. Between 09:00 UTC and 10:00 UTC, when the squall line reaches peak intensity, the total area upward mass flux of $\mathrm{CO}$ exceeds $105000 t \mathrm{~h}^{-1}$, with a maximum grid point value of $460 \mathrm{th}^{-1}$. Values of total area downward mass flux are $-75000 \mathrm{th}^{-1}$, creating a net upward flux of $\sim 30000 t \mathrm{~h}^{-1}$, with a minimum grid point value only $-73 t \mathrm{~h}^{-1}$. The updrafts at $5 \mathrm{~km}$ resolution are more localized and intense than the downdrafts, and CO concentrations in the middle troposphere generally are weaker than those near the surface.

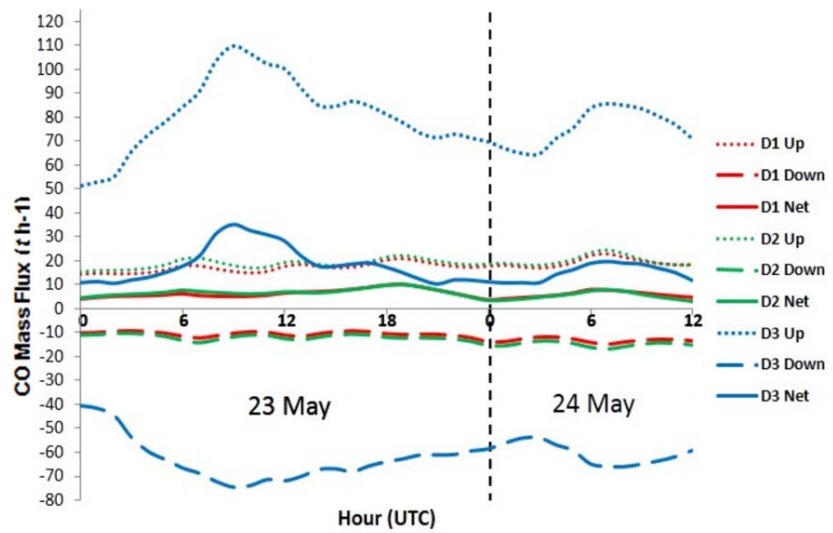

Fig. 14. Time series of hourly CO mass flux within the area of the D3 domain $\left(\times 10^{3}\right.$ metric tonnes $\left.\mathrm{h}^{-1}, t \mathrm{~h}^{-1}\right)$ at $500 \mathrm{hPa}$ starting at 00:00 UTC, 23 May, and ending at 12:00 UTC, 24 May (36 h duration). Values for the area of D3, but at the resolutions of D1 and D2, also are shown. Upward, downward, and net fluxes are given (see legend).

Thus, the upward and downward fluxes do not balance each other and some of the CO remains at $500 \mathrm{hPa}$, thereby increasing the local concentration. As the squall line begins to dissipate after 12:00 UTC, 23 May (Fig. 14), the $5 \mathrm{~km}$ data exhibit a gradual decrease in upward, downward, and net $\mathrm{CO}$ vertical flux over the area and hour considered. Later, as the low pressure system and associated cold front approach the Pacific coast, the weaker multi-cellular convection ahead of the cold front begins at 03:00 UTC, 24 May. This produces a secondary increase in the three types of mass flux, with peaks near 06:00 UTC. While not as great as the squall line related fluxes, upward values exceed $85000 t \mathrm{~h}^{-1}$ and downward flux exceeds $-65000 t \mathrm{~h}^{-1}$, producing a net vertical flux of $\sim 20000 t \mathrm{~h}^{-1}$. Finally, as the convection slowly begins to dissipate after 06:00 UTC, the mass fluxes decrease.

There are important differences (Fig. 14) between the CO vertical fluxes from D3 and those from D1 and D2 that encompass the same area as D3. D3 exhibits two distinct peaks at times of maximum convection; however, D1 and D2 exhibit much weaker peaks. Since convection is parameterized in these two coarser resolution simulations, their convectively induced vertical motions are much weaker than those explicitly resolved in D3.

The vertical fluxes from D1 and D2 exhibit little difference in magnitude (Fig. 14), with values separated by only a few thousand tonnes per hour. This small difference indicates that simply decreasing the horizontal grid spacing from $45 \mathrm{~km}$ to $15 \mathrm{~km}$ does not adequately simulate deep convection in the real atmosphere. Instead, one must explicitly resolve the convection at even smaller grid spacing (e.g., $5 \mathrm{~km}$ ) to approximately simulate real-world convective scenarios. Due to computing requirements, explicitly resolving convection in global models may not be feasible, but including it in 


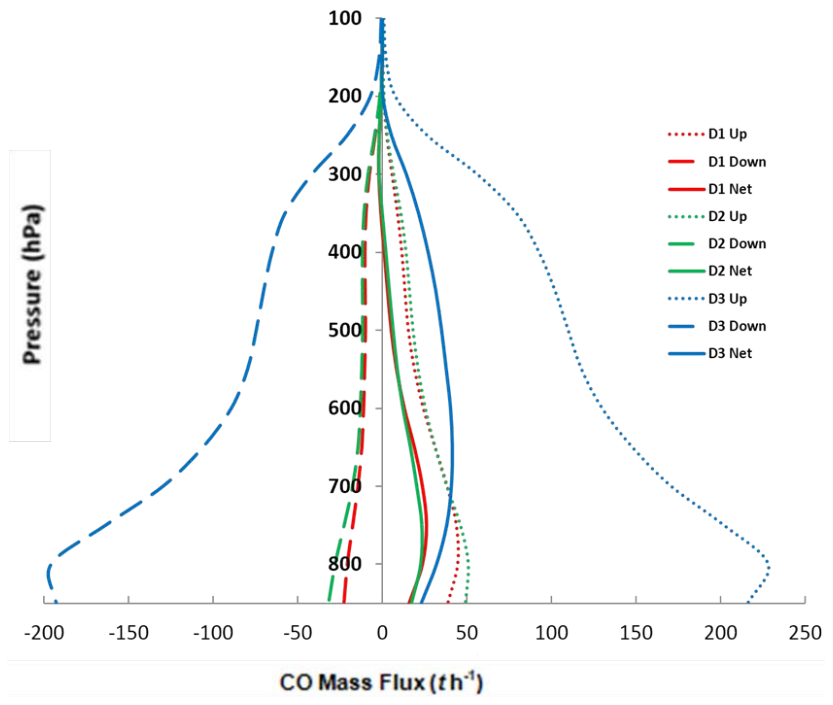

Fig. 15. Vertical profile of CO vertical mass flux $\left(\times 10^{3} t \mathrm{~h}^{-1}\right)$ for the area of domain D3 at 09:00 UTC, 23 May. Values for the area of D3, but at the resolutions of D1 and D2, also are shown. Upward, downward, and net fluxes are given (see legend).

regional studies over areas of deep convection appears crucial.

Profiles of CO vertical mass flux at 09:00 UTC, 23 May (Fig. 15), reveal that the contrasts seen at $500 \mathrm{hPa}$ (Fig. 14) occur throughout the troposphere. The profile was computed over the same area (D3) as Fig. 14, and the same hour of peak squall line intensity. Although the greatest vertical velocities are in the middle troposphere, the largest $\mathrm{CO}$ fluxes are near the surface due to the much greater $\mathrm{CO}$ concentrations in the boundary layer. The $5 \mathrm{~km}$ simulation produces the greatest upward, downward, and net $\mathrm{CO}$ vertical transport at all levels. D1 and D2 again exhibit little difference in their fluxes. Maximum upward fluxes based on D1 and D2 resolution are located somewhat higher in the atmosphere than those from D3 resolution, and their values are approximately an order of magnitude smaller than from D3. All three resolutions produce maximum downward flux in the lower troposphere $(\sim 800 \mathrm{hPa})$.

We examined the vertical transport in greater detail between 04:00 UTC, 23 May, and 07:00 UTC, 24 May (Table 2). Each hour we defined an area of interest (AOI) in the $5 \mathrm{~km}$ domain (D3, Fig. 4) based on simulated radar reflectivity. There was some subjectivity in defining the AOIs. They encompassed the main convective areas of the squall line each hour, including all regions of updrafts and downdrafts. The northern extent of each AOI was located where the convection began to have a more west-to-east than northto-south orientation. The southern boundary of each AOI extended to the southern end of the continuous squall line. In the example at 09:00 UTC (Fig. 4b), the convection in the far southern portion of the box was not considered part of the squall line, but within the next $1-2 \mathrm{~h}$, it merged with the convection to the north and was considered part of the line (Fig. 4b-c). Due to these criteria, the sizes of the AOIs vary considerably during the life cycle of the squall line. The area of each AOI is given in Table 2. We also defined an AOI over the multi-cell coastal convection that occurred near 07:00 UTC, 24 May (Fig. 4d). We then computed CO vertical fluxes within each AOI.

We also computed upward $\mathrm{CO}$ transport within the entire domain of D3 (Table 2) and compared the vertical flux in this entire domain to that of the convection embedded in the AOIs. As the squall line begins to form at 04:00 UTC, the area of the AOI is only $2.6 \%$ of the area of the total D3 region. However, the upward transport due to the squall line AOI is $13.4 \%$ of the total at $700 \mathrm{hPa}, 15.7 \%$ at $500 \mathrm{hPa}$, and $9.8 \%$ at $300 \mathrm{hPa}$. This difference becomes even greater as the squall line develops further. At 09:00 UTC when the squall line is near peak intensity and area coverage, the area of the AOI is approximately $8.4 \%$ of D3, but the transport within the AOI compared to D3's total is $34.1 \%$ at $700 \mathrm{hPa}, 36.9 \%$ at $500 \mathrm{hPa}$, and $41.5 \%$ at $300 \mathrm{hPa}$ (Table 2). Magnitudes are similar at 12:00 UTC, when the area of the AOI is $7.7 \%$ that of D3.

At the time of multi-cell convection at 07:00 UTC, 24 May, the AOI comprises $10.2 \%$ of the total domain (Table 2). However, at $300 \mathrm{hPa}$, the mass flux of $\mathrm{CO}$ is approximately $45.7 \%$ the value of the entire domain, the greatest percentage of any altitude or time. Corresponding percentages at 500 and $700 \mathrm{hPa}$ are $36.7 \%$ and $29.1 \%$, respectively. Even though the convection is weaker than the squall line of the previous day, it still lofts a large amount of CO into the upper troposphere.

\section{Summary and conclusions}

The horizontal and vertical transport of atmospheric pollutants depends greatly on synoptic-scale airstreams such as warm conveyor belts within middle latitude cyclones, mesoscale deep convection that is embedded within them, as well as any deep convection that is located elsewhere. Chemical transport models (CTMs) with a horizontal grid spacing of tens to a few hundred kilometers usually faithfully simulate synoptic-scale meteorological systems. However, they cannot resolve details of convective systems because their relatively coarse grid spacing requires that the convection be parameterized at the resolution of the model. As a result, many facets of the convection are not faithfully represented, including the strong mesoscale vertical motions that can rapidly transport surface-based pollutants high into the atmosphere. Grid spacing less than $\sim 5 \mathrm{~km}$ with explicitly resolved convection is required for this purpose.

This study used the WRF-Chem CTM to simulate a middle latitude cyclone on 23-24 May 2008 that contained a typical WCB with an embedded squall line, as well as deep convection located away from the cyclone. Simulations were 
Table 2. CO mass flux calculations $\left(t \mathrm{~h}^{-1}\right)$ for the entire D3 region (left columns) and their embedded AOIs (right columns) at selected times. Dates and times correspond to the boxes shown in Fig. 4.

\begin{tabular}{|c|c|c|c|c|c|c|c|c|c|c|c|}
\hline & \multirow[b]{2}{*}{ Day } & \multirow[b]{2}{*}{ Hour (UTC) } & \multicolumn{3}{|c|}{ Domain 3} & \multicolumn{6}{|c|}{ Area of Interest Within D3 } \\
\hline & & & Up & Down & Net & Up & Down & Net & Area $\left(\mathrm{km}^{2}\right)$ & $\%$ Area & $\begin{array}{r}\% \text { Upward } \\
\text { Flux }\end{array}$ \\
\hline \multirow{4}{*}{$300 \mathrm{hPa}$} & \multirow{3}{*}{23 May } & 0400 & 27410.7 & -28045.6 & -635.1 & 2693.6 & -1070.5 & 1623.1 & 105850 & 2.6 & 9.8 \\
\hline & & 0900 & 56085.8 & -41775.9 & 14310.3 & 23274.1 & -7509.0 & 15765.1 & 343350 & 8.4 & 41.5 \\
\hline & & 1200 & 57677.1 & -44253.6 & 13423.5 & 23230.4 & -8530.8 & 14699.5 & 315650 & 7.7 & 40.3 \\
\hline & 24 May & 0700 & 40062.7 & -33745.0 & 6317.7 & 18306.2 & -9156.3 & 9149.9 & 420500 & 10.2 & 45.7 \\
\hline \multirow{4}{*}{$500 \mathrm{hPa}$} & \multirow{3}{*}{23 May } & 0400 & 72796.2 & -59802.3 & 12994.2 & 11436.3 & -4560.2 & 6876.1 & 105850 & 2.6 & 15.7 \\
\hline & & 0900 & 109786.0 & -74638.7 & 35147.2 & 40497.1 & -12261.7 & 28235.4 & 343350 & 8.4 & 36.9 \\
\hline & & 1200 & 100312.0 & -72009.4 & 28302.0 & 33178.5 & -11142.5 & 22036.0 & 315650 & 7.7 & 33.1 \\
\hline & 24 May & 0700 & 85641.0 & -65990.4 & 19649.8 & 31466.7 & -11778.2 & 19688.4 & 420500 & 10.2 & 36.7 \\
\hline \multirow{4}{*}{$700 \mathrm{hPa}$} & \multirow{3}{*}{23 May } & 0400 & 123448.0 & -100028.0 & 23420.3 & 16500.6 & -7660.6 & 8840.1 & 105850 & 2.6 & 13.4 \\
\hline & & 0900 & 170631.0 & -129667.0 & 40965.3 & 58100.1 & -27602.6 & 30497.3 & 343350 & 8.4 & 34.1 \\
\hline & & 1200 & 142343.0 & -113256.0 & 29086.6 & 37762.8 & -20878.4 & 16884.5 & 315650 & 7.7 & 26.5 \\
\hline & 24 May & 0700 & 138566.0 & -114071.0 & 24494.9 & 40276.5 & -25597.7 & 14678.9 & 420500 & 10.2 & 29.1 \\
\hline
\end{tabular}

made over three domains (grid spacings of 45,15 , and $5 \mathrm{~km}$ ) to examine $\mathrm{CO}$ transport at the differing resolutions. The model domains were centered over eastern Asia (Fig. 1), completely encompassing the middle latitude cyclone, its associated frontal systems, and flow patterns aloft. Convective parameterization was used in the outer two domains, while convection was explicitly resolved in the innermost domain.

The simulated middle latitude cyclone began near 12:00 UTC, 22 May, and lasted several days (Fig. 2a-d). A WCB was located ahead of the surface cold front with an embedded squall line on 23 May, followed by multi-cellular convection on 24 May (Fig. 4). Locations of these simulated features agreed closely with satellite imagery and WWLLN lightning data (Fig. 3), thereby supporting the validity of the simulations. The cyclone's cold front and associated deep convection passed through an area of surface $\mathrm{CO}$ concentrations exceeding 400 ppbv (Fig. 5), producing vertical transport into the free troposphere where horizontal wind speeds are stronger than near the surface.

Forward trajectories based on the WRF-Chem simulations were calculated using the HYSPLIT model. Comparisons were made between the coarse resolution (D1, $45 \mathrm{~km})$ and finer resolution (D3, $5 \mathrm{~km})$ simulations. Trajectories were launched at 06:00 UTC, 23 May, at $500 \mathrm{~m}$ above ground and run for $48 \mathrm{~h}$ or until they left model domain D1. These trajectories simulated the WCB, with gradual ascent occurring between the surface to 6-7 km altitude (Fig. 6a, c). Trajectories also were launched at a grid spacing of $5 \mathrm{~km}$ (domain D3), encompassing the simulated squall line ahead of the cold front. These trajectories vividly revealed the strong convective transport embedded within the WCB. Rapid ascent to heights $>10 \mathrm{~km}$ occurred within $1 \mathrm{~h}$ of convective initiation (Fig. 6b, d). Both resolutions of trajectories passed through areas of large surface $\mathrm{CO}$ concentrations, allowing us to compare differences in the vertical $\mathrm{CO}$ transport.
The WCB at $45 \mathrm{~km}$ grid spacing lofted $\mathrm{CO}$ values exceeding $275 \mathrm{ppbv}$ from the boundary layer to altitudes of 6-7 km (Fig. 7). The lofted CO plume passed over the cyclone's warm front and then was transported eastward toward the Pacific Ocean. Conversely, $\mathrm{CO}$ transported by the much stronger explicitly resolved convection was rapidly lifted to $10 \mathrm{~km}$. The plume spread horizontally upon reaching the tropopause (Figs. 11-13).

The vertical transport of CO by the squall line on 23 May was much greater than by the multi-cell convection that reformed ahead of the cold front on 24 May. Cross sections of CO parallel and perpendicular to the squall line illustrated the large magnitude of the transport. Along the squall line, $\mathrm{CO}$ was transported to altitudes of $10-12 \mathrm{~km}$ (Fig. 12ab). The multi-cell convection along the coast on 24 May (Fig. 12c) lofted CO to $10-12 \mathrm{~km}$, but the areas of upward transport were more isolated and surface $\mathrm{CO}$ concentrations were smaller. Although these weaker and more separated areas of ascent still transported CO upward and then spread it horizontally, the magnitude of the transport was not as great.

An area of deep convection over southeast China, unrelated to the WCB, also lofted CO to altitudes exceeding $10 \mathrm{~km}$ (Fig. 10). However, this transport occurred relatively slowly because the convection was located in the coarse domain where it was parameterized. Transport to the upper troposphere occurred because the convection persisted for $36 \mathrm{~h}$ over the same area (Fig. 3), allowing the convective parameterization to produce long-lasting but weaker ascent.

$\mathrm{CO}$ vertical mass fluxes were computed at several altitudes over the area encompassed by D3, using WRF-Chem data at each of the three resolutions. Results showed that the simulation at $5 \mathrm{~km}$ grid spacing produced substantially greater upward, downward, and net $\mathrm{CO}$ flux when compared to fluxes based on the output from the coarser D1 and D2 simulations (Fig. 14). Values of upward flux based on the $5 \mathrm{~km}$ grid 
spacing and explicit convection were as large as $50000 t \mathrm{~h}^{-1}$ just before convection began and exceeded $110000 t \mathrm{~h}^{-1}$ during peak intensity of the squall line. Conversely, upward flux from the $45 \mathrm{~km}$ simulation (D1) and $15 \mathrm{~km}$ simulation (D2) never exceeded $25000 t \mathrm{~h}^{-1}$. There were similar differences in magnitudes for the downward and net fluxes during the periods of convection. During a lull in the convection, magnitudes of net fluxes from the three domains were more similar. These resolution differences were evident at all altitudes examined (Fig. 15). The maximum net flux from the $5 \mathrm{~km}$ data occurred at a higher altitude than observed with the D1 or D2 data. However, all three resolutions yielded maximum upward flux near the surface due to large $\mathrm{CO}$ values in the boundary layer.

We further examined the importance of convective transport by defining specific areas of interest (AOIs) within the $5 \mathrm{~km}$ domain (Fig. 4). These AOIs encompassed the simulated squall line and the multi-cell storms that formed later. When the squall line was most intense (09:00 UTC, 23 May), the area of the AOI comprised only $8.4 \%$ of the total D3 domain, but was responsible for $36.9 \%$ of the vertical transport within the domain at $500 \mathrm{hPa}$ (Table 2). Similar contrasting magnitudes were found at other altitudes and times. During the multi-cellular coastal convection on 24 May, the AOI comprised the greatest percentage of the total domain $(10.2 \%)$ and contained $45.7 \%$ of the transport within the domain. Although the convection was multi-cellular and less intense than the squall line of the previous day, it continuously passed over the same area, lofting large amounts of $\mathrm{CO}$ into the atmosphere.

These WRF-Chem simulations reveal major differences in vertical CO transport between parameterized and explicitly resolved convection. Simply decreasing the resolution from $45 \mathrm{~km}$ to $15 \mathrm{~km}$ did not produce major differences in vertical CO transport because parameterization is required at both resolutions. However, the transport was greatly enhanced by increasing the resolution to $5 \mathrm{~km}$, which permitted explicit resolution of the convection. Parameterized convection produces weak ascent, performed with the intent to represent conditions at the coarse resolution of the model. However, this convection must persist to produce significant vertical transport. Conversely, high-resolution simulations with explicit convection begin to loft $\mathrm{CO}$ almost immediately after convective initiation. This contrasting development of convective lifting may greatly affect the patterns of long range $\mathrm{CO}$ transport.

Computing requirements may prohibit the use of highresolution simulations with explicit convection over large or global domains. However, limited area, high-resolution domains could be embedded within a coarse domain to encompass areas of deep convection (Wang et al., 2004), and they could move with the convection to better simulate the rapid vertical transport that occurs there. Alternatively, one could apply an adaptive mesh refinement (AMR) (e.g., Constantinescu et al., 2008) in which the grid adapts dynamically during the simulation, changing the grid resolution at certain intervals (regriding frequency), with the purpose of controlling the numerical spatial discretization error.

Although our findings are for a single case study, we hypothesize that they are applicable to many middle latitude cyclones that contain deep convection, and also to areas of convection not associated with wave cyclones. The results demonstrate the importance of explicitly resolving convection and why it should be used whenever possible. Additional studies must be performed for cyclones and convection of varying strengths and area coverage and in other areas of the globe to better understand convective transport and its influence on atmospheric chemistry.

Acknowledgements. We appreciate the assistance of S. Peckham in running WRF-Chem. Personnel at Florida State University's High Performance Computing center assisted in compiling WRF-Chem and several other programs. L. Emmons at NCAR provided the data from MOZART, and R. Holzworth of the University of Washington provided the WWLLN data. This research was sponsored by the NASA Tropospheric Chemistry Program under grant NNX0AH72G.

Edited by: B. Vogel

\section{References}

Abarca, S. F., Corbosiero, K. L., and Galarneau Jr., T. J.: An evaluation of the Worldwide Lightning Location Network (WWLLN) using the National Lightning Detection Network (NLDN) as ground truth, J. Geophys. Res., 115, D18206, doi:10.1029/2009JD013411, 2010.

ARW WRF User's Guide: National Center for Atmospheric Research, available at: http://www.mmm.ucar.edu/wrf/users/docs/ (last access: March 2012), 2010.

Baldauf, M., Seifert, A., Förstner J., Majewski, D., and Raschendorfer M.: Operational convective-scale numerical weather prediction with the COSMO model: Description and sensitivities, Mon. Weather Rev., 139, 3887-3905, 2011.

Bey, I., Jacob, D. J., Logan, J. A., and Yantosca, R. M.: Asian chemical outflow to the Pacific in spring: Origins, pathways, and budgets, J. Geophys. Res., 106, 23097-23113, doi:10.1029/2001JD000806, 2001.

Byun, D. W. and Schere, K. L.: Review of the governing equations, computational algorithms, and other components of the Models3 Community Multiscale Air Quality (CMAQ) modeling system, Appl. Mech. Rev., 59, 51-77, 2006.

Carlson, T. N.: Airflow through midlatitude cyclones and the comma cloud pattern, Mon. Weather Rev., 108, 1498-1509, 1980.

Carmichael, G. R., Tang, Y., Kurata, G., Uno, I., Streets, D., Woo, J.-H., Huang, H., Yienger, J., Lefer, B., Shetter, R., Blake, D., Atlas, E., Fried, A., Apel, E., Eisele, F., Cantrell, C., Avery, M., Barrick, J., Sachse, G., Brune, W., Sandholm, S., Kondo, Y., Singh, H., Talbot, R., Bandy, A., Thorton, D., Clarke A., and Heikes, B.: Regional-scale chemical transport modeling in support of the analysis of observations obtained 
during the TRACE-P experiment, J. Geophys. Res., 108, 8823, doi:10.1029/2002JD003117, 2003.

Chen, Y., Zhao, C., Zhang, Q., Deng, Z., Huang, M., and Ma, X.: Aircraft study of mountain chimney effect of Beijing, China, J. Geophys. Res., 114, D08306, doi:10.1029/2008JD010610, 2009.

Chin, M., Rood, R. B., Lin, S., Müller, J., and Thompson, A. M.: Atmospheric sulfur cycle simulated in the global model GOCART: Model description and global properties, J. Geophys. Res., 105, 24671-24687, 2000.

Chock, D., Winkler, S., and Sun, P.: Effect of grid resolution and subgrid assumptions on the model prediction of nonhomogeneous atmospheric chemistry, in: The IMA Volumes in Mathematics and its Applications: Atmospheric Modeling, edited by: Chock, D. P. and Carmichael, G. R., 81-108, New York, 2002.

Chou, M. D., Suarez, M. J., Liang, X. Z., and Yan, M. M.: A thermal infrared radiation parameterization for atmospheric studies, NASA/TM-2001-10406, 19, 55 pp., 2001.

Constantinescu, E. M., Sandu, A., and Carmichael, G. R.: Modeling atmospheric chemistry and transport with dynamic adaptive resolution, Comput. Geosci., 12, 133-151, doi:10.1007/s10596007-9065-7, 2008.

Cooper, O. R., Moody, J. L., Parrish, D. D., Trainer, M., Ryerson, T. B., Holloway, J. S., Hübler, G., Fehsenfeld, F. C., Oltmans, S. J., and Evans, M. J.: Trace gas signatures of the airstreams within North Atlantic cyclones: Case studies from the North Atlantic Regional Experiment (NARE '97) aircraft intensive, J. Geophys. Res., 106, 5437-5456, 2001.

Cooper, O. R., Moody, J. L., Parrish, D. D., Trainer, M., Ryerson, T. B., Holloway, J. S., Hübler, G., Fehsenfeld, F. C., and Evans, M. J.: Trace gas composition of midlatitude cyclones over the western North Atlantic Ocean: A conceptual model, J. Geophys. Res., 107, ACH 1-1-ACH 1-13, doi:10.1029/2001JD000901, 2002.

Cooper, O. R., Forster, C., Parrish, D., Trainer, M., Dunlea, E., Ryerson, T., Hübler, G., Fehsenfeld, F., Nicks, D., Holloway, J., de Gouw, J., Warneke, C., Roberts, J. M., Flocke F., and Moody, J.: A case study of transpacific warm conveyor belt transport: Influence of merging airstreams on trace gas import to North America, J. Geophys. Res., 109, D23S08, doi:10.1029/2003JD003624, 2004.

Ding, A., Wang, T., Xue, L., Gao, J., Stohl, A., Lei, H., Jin, D., Ren, Y., Wang, X., Wei, X., Qi, Y., Liu J., and Zhang, X.: Transport of north China air pollution by midlatitude cyclones: Case study of aircraft measurements in summer 2007, J. Geophys. Res., 114, D08304, doi:10.1029/2008JD011023, 2009.

Doherty, R. M., Stevenson, D. S., Collins, W. J., and Sanderson, M. G.: Influence of convective transport on tropospheric ozone and its precursors in a chemistry-climate model, Atmos. Chem. Phys., 5, 3205-3218, doi:10.5194/acp-5-3205-2005, 2005.

Draxler, R. R. and Hess, G. D.: An overview of the HYSPLIT4 modelling system for trajectories, dispersion, and deposition, Aust. Meteorol. Mag., 47, 295-308, 1998.

Eckhardt, S., Stohl, A., Wernli, H., James, P., Forster, C., and Spichtinger, N.: A 15-year climatology of warm conveyor belts, J. Climate, 17, 218-237, 2004.

Ek, M. B., Mitchell, K. E., Lin, Y., Rogers, E., Grunmann, P., Koren, V., Gayno, G., and Tarpley, J. D.: Implementation of Noah land surface model advances in the National Centers for Environ- mental Prediction operational mesoscale Eta model, J. Geophys. Res., 108, 8851, doi:10.1029/2002JD003296, 2003.

Ellingsen, K., Gauss, M., Van Dingenen, R., Dentener, F. J., Emberson, L., Fiore, A. M., Schultz, M. G., Stevenson, D. S., Ashmore, M. R., Atherton, C. S., Bergmann, D. J., Bey, I., Butler, T., Drevet, J., Eskes, H., Hauglustaine, D. A., Isaksen, I. S. A., Horowitz, L. W., Krol, M., Lamarque, J. F., Lawrence, M. G., van Noije, T., Pyle, J., Rast, S., Rodriguez, J., Savage, N., Strahan, S., Sudo, K., Szopa, S., and Wild, O.: Global ozone and air quality: a multi-model assessment of risks to human health and crops, Atmos. Chem. Phys. Discuss., 8, 2163-2223, doi:10.5194/acpd8-2163-2008, 2008.

Emmons, L. K., Walters, S., Hess, P. G., Lamarque, J.-F., Pfister, G. G., Fillmore, D., Granier, C., Guenther, A., Kinnison, D., Laepple, T., Orlando, J., Tie, X., Tyndall, G., Wiedinmyer, C., Baughcum, S. L., and Kloster, S.: Description and evaluation of the Model for Ozone and Related chemical Tracers, version 4 (MOZART-4), Geosci. Model Dev., 3, 43-67, doi:10.5194/gmd3-43-2010, 2010.

Fehsenfeld, F. C., Ancellet, G., Bates, T. S., Goldstein, A. H., Hardesty, R. M., Honrath, R., Law, K. S., Lewis, A. C., Leaitch, R., McKeen, S., Meagher, J., Parrish, D. D., Pszenny, A. A. P., Russell, P. B., Schlager, H., Seinfeld, J., Talbot R., and Zbinden, R.,: International Consortium for Atmospheric Research on Transport and Transformation (ICARTT): North America to Europe Overview of the 2004 summer field study, J. Geophys. Res., 111, D23S01, doi:10.1029/2006JD007829, 2006.

Fiedler, V., Nau, R., Ludmann, S., Arnold, F., Schlager, H., and Stohl, A.: East Asian $\mathrm{SO}_{2}$ pollution plume over Europe - Part 1: Airborne trace gas measurements and source identification by particle dispersion model simulations, Atmos. Chem. Phys., 9, 4717-4728, doi:10.5194/acp-9-4717-2009, 2009.

Fiore, A. M., Jacob, D. J., Bey, I., Yantosca, R. M., Field, B. D., Fusco, A. C., and Wilkinson, J. G.: Background ozone over the United States in summer: Origin, trend, and contribution to pollution episodes, J. Geophys. Res., 107, ACH 11-1-ACH 11-25, doi:10.1029/2001JD000982, 2002.

Gilliam, R. C. and Pleim, J. E.: Performance Assessment of New Land Surface and Planetary Boundary Layer Physics in the WRF-ARW, J. Appl. Meteorol. Clim., 49, 760-774, 2010.

Grell, G. A. and Dévényi, D.: A generalized approach to parameterizing convection combining ensemble and data assimilation techniques, Geophys. Res. Lett., 29, 1693, doi:10.1029/2002GL015311, 2002.

Grell, G. A., Peckham, S. E., Schmitz, R., McKeen, S. A., Frost, G., Skamarock, W. C., and Eder, B.: Fully coupled "online" chemistry within the WRF model, Atmos. Environ., 39, 6957-6975, 2005.

Guenther, A., Karl, T., Harley, P., Wiedinmyer, C., Palmer, P. I., and Geron, C.: Estimates of global terrestrial isoprene emissions using MEGAN (Model of Emissions of Gases and Aerosols from Nature), Atmos. Chem. Phys., 6, 3181-3210, doi:10.5194/acp-63181-2006, 2006.

Halland, J. J., Fuelberg, H. E., Pickering, K. E., and Luo, M.: Identifying convective transport of carbon monoxide by comparing remotely sensed observations from TES with cloud modeling simulations, Atmos. Chem. Phys., 9, 4279-4294, doi:10.5194/acp9-4279-2009, 2009. 
Hannan, J. R., Fuelberg, H. E., Crawford, J. H., Sachse, G. W., and Blake, D. R.: Role of wave cyclones in transporting boundary layer air to the free troposphere during the spring 2001 NASA/TRACE-P experiment, J. Geophys. Res., 108, 8785, doi:10.1029/2002JD003105, 2003.

Harrold, T. W.: Mechanisms influencing the distribution of precipitation within baroclinic disturbances, Q. J. Roy. Meteor. Soc., 99, 232-251, 1973.

Heald, C. L., Jacob, D. J., Fiore, A. M., Emmons, L. K., Gille, J. C., Deeter, M. N., Warner, J., Edwards, D. P., Crawford, J. H., Hamlin, A. J., Sachse, G.W. Browell, E. V., Avery, M. A., Vay, S. A., Westberg, D. J., Blake, D. R., Singh, H. B., Sandholm, S. T., Talbot, R. W., and Fuelberg, H. E.: Asian outflow and transPacific transport of carbon monoxide and ozone pollution: An integrated satellite, aircraft, and model perspective, J. Geophys. Res., 108, 4804, doi:10.1029/2003JD003507, 2003.

Henne, S., Furger, M., Nyeki, S., Steinbacher, M., Neininger, B., de Wekker, S. F. J., Dommen, J., Spichtinger, N., Stohl, A., and Prévôt, A. S. H.: Quantification of topographic venting of boundary layer air to the free troposphere, Atmos. Chem. Phys., 4, 497509, doi:10.5194/acp-4-497-2004, 2004.

Hess, P. G.: A comparison of two paradigms: The relative global roles of moist convective versus nonconvective transport, J. Geophys. Res., 110, D20302, doi:10.1029/2004JD005456, 2005.

Hong, S., Noh, Y., and Dudhia, J.: A new vertical diffusion package with an explicit treatment of entrainment processes, Mon. Weather Rev., 134, 2318-2341, 2006.

Horowitz, L. W., Walters, S., Mauzerall, D. L., Emmons L. K., Rasch, P. J., Granier, C., Tie, X., Lamarque, J.-F., Schultz, M. G., Tyndall, G. S., Orlando, J. J., and Brasseur, G. P.: A global simulation of tropospheric ozone and related tracers: Description and evaluation of MOZART, version 2, J. Geophys. Res., 108, 4784, doi:10.1029/2002JD002853, 2003.

Jacob, D. J.: Introduction to Atmospheric Chemistry, Princeton University Press, Princeton, NJ, 266 pp., 1999.

Jacob, D. J., Logan, J. A., and Murti, P. P.: Effect of rising Asian emissions on surface ozone in the United States, Geophys. Res. Lett., 26, 2175-2178, 1999.

Jacob, D. J., Crawford, J. H., Kleb, M. M., Connors, V. S., Bendura, R. J., Raper, J. L., Sachse, G. W., Gille, J. C., Emmons, L., and Heald, C. L.: Transport and Chemical Evolution over the Pacific (TRACE-P) aircraft mission: Design, execution, and first results, J. Geophys. Res., 108, 9000, doi:10.1029/2002JD003276, 2003.

Jaffe, D., Anderson, T., Covert, D., Kotchenruther, R., Trost, B., Danielson, J., Simpson, W., Berntsen, T., Karlsdottir, S., Blake, D., Harris, J., Carmichael, G., and Uno, I.: Transport of Asian air pollution to North America, Geophys. Res. Lett., 26, 711-714, 1999.

Jaffe, D., Bertschi, I., Jaeglé, L., Novelli, P., Reid, J. S., Tanimoto, H., Vingarzan, R., and Westphal, D. L.: Long-range transport of Siberian biomass burning emissions and impact on surface ozone in western North America, Geophys. Res. Lett., 31, L16106, doi:10.1029/2004GL020093, 2004.

Kiley, C. M. and Fuelberg, H. E.: An examination of summertime cyclone transport processes during Intercontinental Chemical Transport Experiment (INTEX-A), J. Geophys. Res., 111, D24S06, doi:10.1029/2006JD007115, 2006.
Lackmann, G.: Midlatitude Synoptic Meteorology: Dynamics, Analysis, and Forecasting, Amer. Meteor. Soc., Boston, 360 pp., 2011.

Lawrence, M. G., von Kuhlmann, R., Salzmann, M., and Rasch, P. J.: The balance of effects of deep convective mixing on tropospheric ozone, Geophys. Res. Lett., 30, 1940-1943, doi:10.1029/2003GL017644, 2003.

Li, Q., Jacob, D. J., Park, R., Wang, Y., Heald, C. L., Hudman, R., Yantosca, R. M., Martin, R. V., and Evans, M.: North American pollution outflow and the trapping of convectively lifted pollution by upper-level anticyclone, J. Geophys. Res., 110, D10301, doi:10.1029/2004JD005039, 2005.

Liang, Q., Jaeglé, L., Jaffe, D. A., Weiss-Penzias, P., Heckman, A., and Snow, J. A.: Long-range transport of Asian pollution to the northeast Pacific: Seasonal variations and transport pathways of carbon monoxide, J. Geophys. Res., 109, D23S07, doi:10.1029/2003JD004402, 2004.

Lin, M., Holloway, T., Oki, T., Streets, D. G., and Richter, A.: Multiscale model analysis of boundary layer ozone over East Asia, Atmos. Chem. Phys., 9, 3277-3301, doi:10.5194/acp-9-3277-2009, 2009.

Lin, M., Holloway, T., Carmichael, G. R., and Fiore, A. M.: Quantifying pollution inflow and outflow over East Asia in spring with regional and global models, Atmos. Chem. Phys., 10, 42214239, doi:10.5194/acp-10-4221-2010, 2010.

Lin, M., Fiore, A. M., Horowitz, L. W., Cooper, O. R., Naik, V., Holloway, J., Johnson, B. J., Middlebrook, A. M., Oltmans, S. J., Pollack, I. B., Ryerson, T. B., Warner, J. X., Wiedinmyer, C., Wilson, J., and Wyman, B.: Transport of Asian ozone pollution into surface air over the western United States in spring, J. Geophys. Res., 117, D00V07, doi:10.1029/2011JD016961, 2012.

Lin, Y., Farley, R. D., and Orville, H. D.: Bulk Parameterization of the Snow Field in a Cloud Model, J. Clim. Appl. Meteorol., 22, 1065-1092, 1983.

Liu, H., Jacob, D. J., Bey, I., Yantosca, R. M., Duncan, B. N., and Sachse, G. W.: Transport pathways for Asian pollution outflow over the Pacific: Interannual and seasonal variations, J. Geophys. Res., 108, 8786, doi:10.1029/2002JD003102, 2003.

Madronich, S.: Photodissociation in the Atmosphere: 1 . Actinic flux and the effects of ground reflections and clouds, J. Geophys. Res., 92, 9740-9752, 1987.

Markowski, P. and Richardson, Y.: Mesoscale Meteorology in Midlatitudes, John Wiley \& Sons, Ltd, Chichester, UK, 2010.

Mlawer, E. J., Taubman, S. J., Brown, P. D., Iacono, M. J., and Clough, S. A.: Radiative transfer for inhomogeneous atmospheres: RRTM, a validated correlated-k model for the longwave, J. Geophys. Res., 102, 16663-16682, 1997.

Naja, M., Akimoto, H., and Staehelin, J.: Ozone in background and photochemically aged air over central Europe: Analysis of longterm ozonesonde data from Hohenpeissenberg and Payerne, J. Geophys. Res., 108, 4063, doi:10.1029/2002JD002477, 2003.

Novelli, P. C., Masarie, K. A., and Lang, P. C.: Distributions and recent changes of carbon monoxide in the lower troposphere. J. Geophys. Res., 103, 19015-19033, 1998.

Ohara, T., Akimoto, H., Kurokawa, J., Horii, N., Yamaji, K., Yan, X., and Hayasaka, T.: An Asian emission inventory of anthropogenic emission sources for the period 1980-2020, Atmos. Chem. Phys., 7, 4419-4444, doi:10.5194/acp-7-4419-2007, 2007. 
Oltmans, S. J., Lefohn, A. S., Harris, J. M., and Shadwick, D. S.: Background ozone levels of air entering the west coast of the US and assessment of longer-term changes, Atmos. Environ., 42, 6020-6038, 2008.

Park, R. J., Stenchikov, G. L., Pickering, K. E., Dickerson, R. R., Allen, D. J., and Kondragunta, S.: Regional air pollution and its radiative forcing: Studies with a single-column chemical and radiation transport model, J. Geophys. Res., 106, 28751-28770, 2001.

Pickering, K. E., Thompson, A. M., Wang, Y., Tao, W.-K., McNamara, D. P., Kirchhoff, V. W. J. H., Heikes, B. G., Sachse, G. W., Bradshaw, J. D., Gregory, G. L., and Blake. D. R.: Convective transport of biomass burning emissions over Brazil during TRACE A, J. Geophys. Res., 101, 23993-24012, 1996.

Purvis, R. M., Lewis, A. C., Carney, R. A., McQuaid, J. B., Arnold, S. R., Methven, J., Barjat, H., Dewey, K., Kent, J., Monks, P. S., Carpenter, L. J., Brough, N., Penkett S. A., and Reeves, C.: Rapid uplift of nonmethane hydrocarbons in a cold front over central Europe, J. Geophys. Res., 108, 4224, doi:10.1029/2002JD002521, 2003.

Reidmiller, D. R., Fiore, A. M., Jaffe, D. A., Bergmann, D., Cuvelier, C., Dentener, F. J., Duncan, B. N., Folberth, G., Gauss, M., Gong, S., Hess, P., Jonson, J. E., Keating, T., Lupu, A., Marmer, E., Park, R., Schultz, M. G., Shindell, D. T., Szopa, S., Vivanco, M. G., Wild, O., and Zuber, A.: The influence of foreign vs. North American emissions on surface ozone in the US, Atmos. Chem. Phys., 9, 5027-5042, doi:10.5194/acp-9-5027-2009, 2009.

Richter, A., Burrows, J. P., Nüß, H., Granier, C., and Niemeier, U.: Increase in tropospheric nitrogen dioxide over China observed from space, Nature, 437, 129-132, 2005.

Rodger, C. J., Brundell, J. B., Dowden, R. L., and Thomson, N. R.: Location accuracy of long distance VLF lightning locationnetwork, Ann. Geophys., 22, 747-758, doi:10.5194/angeo-22-7472004, 2004.

Rodger, C. J., Brundell, J. B., Holzworth, R. H., and Lay, E. H.: Growing detection efficiency of the world wide lightning location network, AIP Conf. Proc., 1118, 15-20, doi:10.1063/1.3137706, 2009.

Sato, T., Yoshikane, T., Satoh, M., Miura, H., and Fujinami, H.: Resolution dependency of the diurnal cycle of convective clouds over the Tibetan Plateau in a mesoscale model, J. Meteorol. Soc. Jpn., 86, 17-31, 2008.

Singh, H. B., Brune, W. H., Crawford, J. H., Flocke, F., and Jacob, D. J.: Chemistry and transport of pollution over the Gulf of Mexico and the Pacific: spring 2006 INTEX-B campaign overview and first results, Atmos. Chem. Phys., 9, 2301-2318, doi:10.5194/acp-9-2301-2009, 2009.

Srivastava, R., McRae, D., and Odman, M.: Simulation of a reacting pollutant puff using an adaptive grid algorithm, J. Geophys. Res., 106, 224-257, 2001a.

Srivastava, R., McRae, D., and Odman, M.: Simulation of dispersion of a power plant plume using an adaptive grid algorithm, Atmos. Environ., 35, 4801-4818, 2001 b.

Skamarock, W. C., Klemp, J. B., Dudhia, J., Gill, D. O., Baker, D. M., Duda, M. G., Huang, X., Wang, W., and Powers, J. G.: A description of the Advanced Research WRF version 3, NCAR Tech. Note NCAR/TN-475+STR, 113 pp., 2008.
Stockwell, W. R., Kirchner, F., Kuhn, M., and Seefeld, S.: A new mechanism for regional atmospheric chemistry modeling, J. Geophys. Res., 102, 25847-25879, 1997.

Stohl, A.: A 1-year Lagrangian "climatology" of airstreams in the Northern Hemisphere troposphere and lowermost stratosphere, J. Geophys. Res., 106, 7263-7279, 2001.

Stohl, A. and Trickl, T.: A textbook example of long-range transport: Simultaneous observation of ozone maxima of stratospheric and North American origin in the free troposphere over Europe, J. Geophys. Res., 104, 30445-30462, 1999.

Stohl, A., Eckhardt, S., Forster, C., James, P., and Spichtinger, N.: On the pathways and timescales of intercontinental air pollution transport, J. Geophys. Res., 107, 4684, doi:10.1029/2001JD001396, 2002.

Stohl, A., Forster, C., Huntrieser, H., Mannstein, H., McMillan, W. W., Petzold, A., Schlager, H., and Weinzierl, B.: Aircraft measurements over Europe of an air pollution plume from Southeast Asia - aerosol and chemical characterization, Atmos. Chem. Phys., 7, 913-937, doi:10.5194/acp-7-913-2007, 2007.

Taylor, Z. B.: The impact of cumulus parameterization schemes on the convective transport of biomass burning emissions using WRF-Chem (Master's thesis), retrieved from the Florida State University Electronic Theses, Treatises and Dissertations (URN No. etd-03172011-202134), 2011.

Thompson, A. M., Pickering, K. E., Dickerson, R. R., Ellis Jr., W. G., Jacob, D. J., Scala, J. R., Tao, W., McNamara, D. P., and Simpson, J.: Convective transport over the central United States and its role in regional CO and ozone budgets, J. Geophys. Res., 99, 18703-18711, 1994.

Thompson, A. M., Tao, W., Pickering, K. E., Scala, J. R., and Simpson, J.: Tropical deep convection and ozone formation, B. Am. Meteorol. Soc., 78, 1043-1054, 1997.

Tie, X., Brasseur, G., and Ying, Z.: Impact of model resolution on chemical ozone formation in Mexico City: application of the WRF-Chem model, Atmos. Chem. Phys., 10, 8983-8995, doi:10.5194/acp-10-8983-2010, 2010.

Tzella, A. and Legras, B.: A Lagrangian view of convective sources for transport of air across the Tropical Tropopause Layer: distribution, times and the radiative influence of clouds, Atmos. Chem. Phys., 11, 12517-12534, doi:10.5194/acp-11-12517-2011, 2011.

US National Centers for Environmental Protection, updated daily: NCEP FNL Operational Model Global Tropospheric Analyses, continuing from July 1999. Dataset ds083.2 published by the CISL Data Support Section at the National Center for Atmospheric Research, Boulder, CO, available online at: http://dss. ucar.edu/datasets/ds083.2/ (last access: May 2012), 2012.

Wang, Y., McElroy, M., Jacob, D., and Yantosca, R.: A nested grid formulation for chemical transport over Asia: Applications to CO, J. Geophys. Res., 109, D22307, doi:10.1029/2004JD005237, 2004.

Warner, T. T., Peterson, R. A., and Treadon, R. E.: A tutorial on lateral boundary conditions as a basic and potentially serious limitation to regional numerical weather prediction, B. Am. Meteorol. Soc., 78, 2599-2617, 1997.

Weisman, M. L., Skamarock, W. C., and Klemp, J. B.: The resolution dependence of explicitly modeled convective systems, Mon. Weather Rev., 125, 527-548, 1997.

Wiedinmyer, C., Akagi, S. K., Yokelson, R. J., Emmons, L. K., AlSaadi, J. A., Orlando, J. J., and Soja, A. J.: The Fire INventory 
from NCAR (FINN): a high resolution global model to estimate the emissions from open burning, Geosci. Model Dev., 4, 625641, doi:10.5194/gmd-4-625-2011, 2011.

Wolke, R., Schröder, W., Schrödner, R., and Renner, E.: Influence of grid resolution and meteorological forcing on simulated European air quality: A sensitivity study with the modeling system COSMO-MUSCAT, Atmos. Environ., 53, 110-130, 2012.

Yienger, J. J, Galanter, M., Holloway, T. A, Phadnis M. J., Guttikunda, S. K., Carmichael, G. R., Moxim, W. J., and Levy II, H.: The episodic nature of air pollution transport from Asia to North America, J. Geophys. Res., 105, 26931-26945, 2000.

Zhang, L., Jacob, D. J., Boersma, K. F., Jaffe, D. A., Olson, J. R., Bowman, K. W., Worden, J. R., Thompson, A. M., Avery, M. A., Cohen, R. C., Dibb, J. E., Flock, F. M., Fuelberg, H. E., Huey, L. G., McMillan, W. W., Singh, H. B., and Weinheimer, A. J.: Transpacific transport of ozone pollution and the effect of recent Asian emission increases on air quality in North America: an integrated analysis using satellite, aircraft, ozonesonde, and surface observations, Atmos. Chem. Phys., 8, 6117-6136, doi:10.5194/acp-8-6117-2008, 2008.
Zhang, Q., Streets, D. G., He, K., Wang,Y., Richter, A., Burrows, J. P., Uno, I., Jang, C. J., Chen, D., Yao, Z., and Lei, Y.: $\mathrm{NO}_{\mathrm{x}}$ emission trends for China, 1995-2004: The view from the ground 30 and the view from space, J. Geophys. Res., 112, D22306, doi:10.1029/2007JD008684, 2007.

Zhang, Q., Streets, D. G., Carmichael, G. R., He, K. B., Huo, H., Kannari, A., Klimont, Z., Park, I. S., Reddy, S., Fu, J. S., Chen, D., Duan, L., Lei, Y., Wang, L. T., and Yao, Z. L.: Asian emissions in 2006 for the NASA INTEX-B mission, Atmos. Chem. Phys., 9, 5131-5153, doi:10.5194/acp-9-5131-2009, 2009.

Zhao, C., Wang, Y., Choi, Y., and Zeng, T.: Summertime impact of convective transport and lightning $\mathrm{NO}_{\mathrm{x}}$ production over North America: modeling dependence on meteorological simulations, Atmos. Chem. Phys., 9, 4315-4327, doi:10.5194/acp-9-43152009, 2009. 